\title{
Synergistic Adsorption and Photocatalytic Activity under Visible Irradiation Using Ag-ZnO/GO Nanoparticles Derived at Low Temperature
}

\author{
Viet Ha Tran Thi $\mathbb{D}^{1},{ }^{1}$ The Ha Cao $\mathbb{D}^{1},{ }^{1,2}$ Tri Nhut Pham $\mathbb{D}^{3},{ }^{3,4}$ Tien Thanh Pham ${ }^{5}{ }^{5}$ \\ and Manh Cuong Le $\mathbb{1}^{6}$ \\ ${ }^{1}$ Master's Program in Environmental Engineering, Vietnam Japan University, Hanoi, Vietnam \\ ${ }^{2}$ Center for Environmental Technology and Sustainable Development (CETASD), Hanoi, Vietnam \\ ${ }^{3}$ Center of Excellence for Green Energy and Environmental Nanomaterials, Nguyen Tat Thanh University, \\ Ho Chi Minh City, Vietnam \\ ${ }^{4}$ NTT Hi-Tech Institute, Nguyen Tat Thanh University, Ho Chi Minh City, Vietnam \\ ${ }^{5}$ Master's Program in Nano Technology, Vietnam Japan University, Hanoi, Vietnam \\ ${ }^{6}$ Department of Building Materials, National University of Civil Engineering, Hanoi, Vietnam
}

Correspondence should be addressed to Viet Ha Tran Thi; ttv.ha@vju.ac.vn

Received 7 March 2019; Revised 30 May 2019; Accepted 27 June 2019; Published 18 September 2019

Guest Editor: Nguayen Van Noi

Copyright (C) 2019 Viet Ha Tran Thi et al. This is an open access article distributed under the Creative Commons Attribution License, which permits unrestricted use, distribution, and reproduction in any medium, provided the original work is properly cited.

\begin{abstract}
Ag- $\mathrm{ZnO} /$ graphene oxide ( $\mathrm{AG}-\mathrm{ZnO} / \mathrm{GO}$ ) nanocomposite was synthesized via facile aqueous solution reactions at low temperature in order to improve the photocatalytic activity for cationic dye removal under visible light irradiation. Analytical techniques were carried out in order to determine the abilities including structure, state of elements, morphology, and surface area of synthesized materials. Ag- $\mathrm{ZnO} / \mathrm{GO}$ nanocomposite presented an extremely high removal rate of methylene blue (MB) not only under UV light (over 99\% removal) but also under visible light (85\% removal) during the same irradiation time. In this study, initial process parameters of catalyst dosage, $\mathrm{MB}$ concentration, and $\mathrm{pH}$ of the solution were also examined for $\mathrm{MB}$ removal efficiency effects. The proposed mechanisms for the increased removal of $\mathrm{MB}$ by $\mathrm{Ag}-\mathrm{ZnO} / \mathrm{GO}$ nanocomposite under visible irradiation include increased photocatalytic degradation, mainly due to increased charge transfer capacity by lowering band gap energy; minimized recombination of the excited electron-hole pairs of $\mathrm{ZnO}$ with the addition of $\mathrm{Ag}$ into the $\mathrm{ZnO}$ crystal lattice; and an increased adsorption capacity with the addition of GO with high surface area and semiconductor function with zero band gap energy.
\end{abstract}

\section{Introduction}

Developing semiconductor photocatalysts has been considered a promising green technology for solving environmental issues. Among various semiconductors, zinc oxide $(\mathrm{ZnO})$ has been considered one of the most promising photocatalysts because of its outstanding properties, such as physical and chemical stability, low cost, and nontoxicity. Thus, $\mathrm{ZnO}$ has been widely used for many different applications such as in optical materials, sensors, solar energy conversion devices, and photocatalysts for pollutant treatment. $\mathrm{ZnO}$ also has several advantages over $\mathrm{TiO}_{2}$ - the most popular photocatalyst [1], which includes higher thermal stability and easier and less expensive synthesis [2]. However, the photocatalytic performance of $\mathrm{ZnO}$ is reduced because of its wide band gap (theoretical $\sim 3.2 \mathrm{eV}$ at room temperature) [3] and high recombination rate between photogenerated electrons from the conduction band (CB) and holes from the valence band (VB) [4]. Such a noble metal modification can also influence the surface properties, in particular, by introducing hydroxyl groups on the surface of the photocatalysts [5-7]. However, these modifications require calcination at high temperature 
$\left(400-600^{\circ} \mathrm{C}\right)$ and the consequent need for strict control which hinders large-scale production.

Graphene sheets possess a unique two-dimensional layered structure of $\mathrm{sp}^{2}$-hybridized carbon atoms, and thus, they can exhibit novel electronic properties as zero band gap semiconductors. Ahmad et al. synthesized graphene-Ag/ $\mathrm{ZnO}$ nanocomposite via a solvothermal method [8]. However, it is not easy to synthesize due to high levels of impurities with graphene; thus, oxidized forms are usually used as a substitute for graphene in many research studies. In addition, graphene oxide (GO) provides a large scaffold for anchoring various substances owing to its large specific surface area [9] and two-dimensional planar conjugated structure. For example, GO bonding with $\mathrm{TiO}_{2}$ or $\mathrm{WO}_{3}$ composites has been widely investigated $[10,11]$. Moreover, GO-based photocatalysts can avoid the aggregation of nanoparticles anchored on graphene sheets, which can provide more reactive sites for the photocatalytic degradation process. For instance, Nasrollahzadeh et al. reported on the synthesis and use of graphene oxide/ $\mathrm{ZnO}$ nanocomposite as a heterogeneous catalyst for the synthesis of various tetrazoles [12]. Easy separation of the GO-based photocatalysts used for organic removal from water systems offers other benefits for repeated catalyst use and wide industrial applications $[13,14]$. However, most of the derived nanoparticles need to be calcinated at high temperature; thus, GO can form reduced GO ( $\mathrm{rGO}$ ) or other forms of $\mathrm{GO}$. Raj Pant et al. synthesized Ag-ZnO/rGO nanocomposite in an autoclave at $140^{\circ} \mathrm{C}$ [15], and Gao et al. synthesized sulfonated graphene oxide- $\mathrm{ZnO}-\mathrm{Ag}$ photocatalyst at $300^{\circ} \mathrm{C}$ [13]. Only limited reports are available for different fabrication methods of $\mathrm{Ag}-\mathrm{ZnO} / \mathrm{GO}$ to treat organic pollutants under UV light [16].

Herein, we report a novel fabrication method of Ag$\mathrm{ZnO} / \mathrm{GO}$ nanocomposite and its characterizations, and then apply it for use in effective removal of the cationic dye methylene blue (MB) in an aqueous solution. This study also aims to save energy and costs by using a novel synthesis method at low temperature, with visible lamps rather than UV lamps as the light source of the photocatalytic process. A suitable photocatalytic degradation mechanism for enhanced $\mathrm{MB}$ removal was also proposed.

\section{Materials and Methods}

2.1. Preparation of Photocatalysts. Sodium hydroxide $(\mathrm{NaOH})$, silver nitrate $\left(\mathrm{AgNO}_{3}\right)$, zinc sulfate heptahydrate $\left(\mathrm{ZnSO}_{4} \cdot 7 \mathrm{H}_{2} \mathrm{O}\right)$, ascorbic acid $\left(\mathrm{C}_{6} \mathrm{H}_{6} \mathrm{O}_{6}\right)$, and $\mathrm{MB}$ $\left(\mathrm{C}_{16} \mathrm{H}_{18} \mathrm{~N}_{3} \mathrm{SCl}\right)$ were purchased from DaeJung Chemicals \& Metals Co., Ltd., Korea. GO was purchased from Sigma-Aldrich Co LLC. All purchased chemicals were used without any further purification. Distilled water was used for experiments.

$\mathrm{ZnO}$ nanoparticles were prepared by dropwise addition of $25 \mathrm{~mL}$ of $\mathrm{NaOH} 0.4 \mathrm{~mol} / \mathrm{L}$ into $25 \mathrm{~mL}$ of $\mathrm{ZnSO}_{4} 0.2 \mathrm{~mol} / \mathrm{L}$ at an approximate addition rate of $5 \mathrm{~mL} / \mathrm{min}$. After stirring with a magnetic stirrer (GLHPS-G, Global Lab., Ltd.) at a speed of $150 \mathrm{rpm}$ for $60 \mathrm{~min}$, the solution was kept at $60^{\circ} \mathrm{C}$ for $2 \mathrm{~h}$.
The Ag- $\mathrm{ZnO}$ composite nanoparticles were prepared by adding $6 \mathrm{~mL}$ of ascorbic acid $0.01 \mathrm{~mol} / \mathrm{L}$ and $13 \mathrm{~mL}$ of $\mathrm{AgNO}_{3} 0.01 \mathrm{~mol} / \mathrm{L}$ into the solution of $\mathrm{NaOH}$ and $\mathrm{ZnSO}_{4}$, while stirring under the same condition as in the first experiment, and again the solution was kept at $70^{\circ} \mathrm{C}$ for $2 \mathrm{~h}$.

For the preparation of $\mathrm{Ag}-\mathrm{ZnO} / \mathrm{GO}$, the steps of the $\mathrm{Ag}-\mathrm{ZnO}$ synthesis procedure were repeated. At the same time, $50 \mathrm{mg}$ of GO was mixed into $50 \mathrm{~mL}$ water in an ultrasonicator (D250H, DAIHAN Scientific, Co., Ltd.) for $30 \mathrm{~min}$ at room temperature. The two solutions were then mixed, and the final solution obtained was kept at $70^{\circ} \mathrm{C}$ for $2 \mathrm{~h}$. In the last step, the synthesized products were centrifuged and washed with deionized water several times and dried in a vacuum at $70^{\circ} \mathrm{C}$ for $24 \mathrm{~h}$.

2.2. Characterization. The synthesized reaction products were characterized by X-ray diffraction (XRD; Bruker AXS D8 ADVANCE) to identify the structure and phase composition. Wide-angle patterns were recorded from $2 \theta=10^{\circ}$ to $80^{\circ}$ using a step size of $0.1^{\circ}$. Their surface morphologies and microstructures were examined using field emission scanning electron microscopy (FE-SEM; JEOL, JSM-6500F, $10 \mathrm{kV}$ ) and transmission electron microscopy (TEM; JEOL, JEM-2100F). Composition mapping of the major elements on the material surface was carried out using energy dispersive X-ray spectroscopy (EDS; JEOL, JSM-6500F). The surface compositions and chemical states were measured by using X-ray photoelectron spectroscopy (XPS; Thermo Fisher Scientific, ESCALAB 250XI). The specific surface areas of the compounds were determined by the Brunauer-Emmett-Teller (BET) method using nitrogen gas adsorption. Room temperature photoluminescence (PL) spectra were recorded using a fluorescence spectrometer.

The visible light absorption of the synthesized products was measured in the range of 400 to $800 \mathrm{~nm}$ using a UV-Vis spectrophotometer (GENESYS ${ }^{\mathrm{TM}} 10 \mathrm{~S}$ UV-Vis., USA) with integrating sphere accessories. To plot the calibration curve of $\mathrm{MB}$ dye, aqueous dye solutions were prepared at a concentration ranging from 1 to $25 \mathrm{mg} / \mathrm{L}$ by using distilled water. The concentrations of the MB solutions were determined using the obtained calibration curve. The dye removal efficiency was calculated based on following equation:

$$
\text { Removal efficiency }(\%)=\frac{C_{0}-C}{C_{0}} \times 100 \% \text {, }
$$

where $\mathrm{C}_{0}(\mathrm{mg} / \mathrm{L})$ is the concentration of the $\mathrm{MB}$ solution at the initial time $t=0(\mathrm{~min})$ and $\mathrm{C}(\mathrm{mg} / \mathrm{L})$ is the concentration after the treatment reaction in a dark condition or after UVvisible light irradiation.

2.3. Photocatalytic Activity Measurement. The photocatalytic activity of the synthesized materials was estimated by using an illumination system consisting of five lamps [visible lamp (EFTR 20EX-D, Kumho Co., Ltd., Republic of Korea)/UV lamp (AL-2220D1 20W, Alim Co., Ltd, the Republic of Korea)] as irradiation sources. In a typical process, $20 \mathrm{mg}$ of the synthesized photocatalyst was suspended in $20 \mathrm{~mL}$ of $\mathrm{MB}$ 
with a concentration of $15 \mathrm{mg} / \mathrm{L}$ in a cylindrical glass reactor. Before starting the photocatalytic reaction, the suspension was stirred for $30 \mathrm{~min}$ in a dark condition to obtain an adsorption/desorption equilibrium between the dye and the photocatalyst. Photocatalytic reactions were carried out under a stable condition (stirring speed of $80 \mathrm{rpm}$ at intervals of $3 \mathrm{~h}$ under light irradiation).

To clarify the dominant radical or ion on the photocatalysis reaction, the experiments using different radical scavengers were performed. Scavengers including tert-butyl alcohol, benzoquinone, ammonium oxalate, and $\mathrm{K}_{2} \mathrm{~S}_{2} \mathrm{O}_{8}$ were used for $\mathrm{OH}^{\bullet}, \mathrm{O}_{2}{ }^{\bullet}$, holes and electrons, respectively. The experiment was carried out similar to the removal experiment with the added radical scavenger $(0.1 \mathrm{mmol})$.

\section{Results and Discussions}

\subsection{Characterization of Material}

3.1.1. XRD Pattern Analysis. Figure 1 showed the XRD patterns of the $\mathrm{ZnO}$ and $\mathrm{Ag}-\mathrm{ZnO} / \mathrm{GO}$ samples. The Ag-ZnO/GO spectrum included a diffraction peak at $2 \theta=11.5^{\circ}$ of pristine $\mathrm{GO}[17,18]$, indicating that the major form of graphene in the synthesized material was GO. In both $\mathrm{ZnO}$ and $\mathrm{Ag}-\mathrm{ZnO} / \mathrm{GO}$ spectra, the observed diffraction peaks at $2 \theta=32,34$, and $36^{\circ}$ confirmed the presence of the hexagonal wurtzite structure of $\mathrm{ZnO}$. In general, the intensity of the diffraction peaks decreases greatly with the increase in doping concentration [19]. Thus, it can be observed that the peak intensity of $\mathrm{ZnO}$ in the $\mathrm{Ag}-\mathrm{ZnO} / \mathrm{GO}$ sample was decreased as compared with that of the $\mathrm{ZnO}$ sample. Besides, the XRD pattern of $\mathrm{Ag}-\mathrm{ZnO} / \mathrm{GO}$ mainly showed a small silver peak at $2 \theta=38^{\circ}$ [20-22], and this confirmed the doping activity of Ag onto the structure of $\mathrm{ZnO}$. Simultaneously, a small amount of $\mathrm{Ag}$ entered the $\mathrm{ZnO}$ crystal structure, as confirmed by the broadening at $2 \theta=32,34$, and $36^{\circ}$ in the $\mathrm{Ag}-\mathrm{ZnO} / \mathrm{GO}$ peaks compared to $\mathrm{ZnO}$ peaks $[23,24]$. The value of full width at half maximum (FWHM) of diffraction peak is showed on Table 1.

3.1.2. Morphology and Microstructure by SEM and TEM Analysis. FE-SEM and TEM analyses were used to identify the morphology and microstructure of the synthesized materials. The SEM images of $\mathrm{ZnO}$ before addition of $\mathrm{Ag}$ and GO exhibited high degree of uniformity in the nanosized $\mathrm{ZnO}$ particles (Figures 2(a) and 2(b)). When GO was introduced into the composites, numerous $\mathrm{Ag}-\mathrm{ZnO}$ nanoparticles were deposited on the GO sheets (Figures 2(c) and 2(d)). In the Ag- $\mathrm{ZnO} / \mathrm{GO}$ heterostructure, $\mathrm{GO}$ sheets were consistently decorated with $\mathrm{Ag}$ and $\mathrm{ZnO}$ nanoparticles. TEM images revealed a hexagonal shape for $\mathrm{ZnO}$ (Figure 2(e)) with a diameter $50-60 \mathrm{~nm}$, which is in good agreement with the diameter of $\mathrm{ZnO}$ revealed in SEM images. Figure 2(f) shows the TEM image of Ag- $\mathrm{ZnO} / \mathrm{GO}$ composite, demonstrating the attendance of few-layered GO sheets decorated with $\mathrm{Ag}$ and $\mathrm{ZnO}$ particles which may result in better adsorption capacity and electron-hole separation.

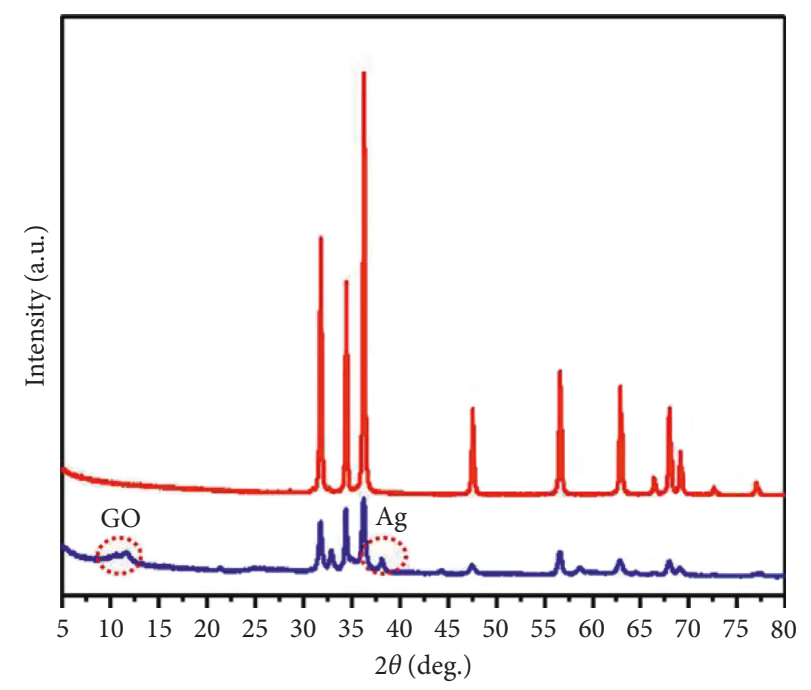

$-\mathrm{ZnO}$

- Ag- ZnO/GO

Figure 1: XRD patterns of the $\mathrm{ZnO}$ and $\mathrm{Ag}-\mathrm{ZnO} / \mathrm{GO}$ samples.

TABLE 1: FWHM in the samples.

\begin{tabular}{lc}
\hline Sample & FWHM $\left(\mathrm{cm}^{-1}\right)$ \\
\hline $\mathrm{ZnO}$ & 0.2210 \\
$\mathrm{Ag}-\mathrm{ZnO} / \mathrm{GO}$ & 0.2377 \\
\hline
\end{tabular}

The chemical compositions of $\mathrm{ZnO}$ and $\mathrm{Ag}-\mathrm{ZnO} / \mathrm{GO}$ were analyzed by energy dispersive spectrometry (EDS) and mapping technique in conjunction with SEM (Figure 3). All the peaks were ascribed to $\mathrm{Zn}, \mathrm{Ag}$, and $\mathrm{O}$ in the $\mathrm{ZnO}$ sample, and peak of $\mathrm{C}$ elements appeared in the composite sample. The mapping results confirmed the presence and uniform distribution of zinc, silver, and oxygen on the GO surface. In combination, these elemental mapping and SEM and TEM results demonstrate the capability of GO to function as an effective scaffold for $\mathrm{ZnO}$ and silver.

3.1.3. XPS Analysis. The surface element composition and chemical state of the as-synthesized samples were analyzed by XPS analysis, as shown in Figure 4 . The peaks of $Z n 2 p_{3 / 2}$ and $\mathrm{Zn} 2 \mathrm{p}_{1 / 2}$ of the synthesized $\mathrm{ZnO}$ and $\mathrm{Ag}$ - $\mathrm{ZnO} / \mathrm{GO}$ were observed at around $1,021.8 \mathrm{eV}$ and $1,045.1 \mathrm{eV}$, respectively, which are very similar to the peaks of pure $\mathrm{ZnO}$ (Figure 4(a)). This finding, therefore, demonstrated the presence of the $\mathrm{Zn}^{2+}$ form in both samples $[19,25]$. In the $\mathrm{C} 1$ s spectra of $\mathrm{Ag}-\mathrm{ZnO} / \mathrm{GO}$ (Figure 4(b)), the presence of $\mathrm{C}$ was attributed to the $\mathrm{GO}$ addition. Compared to $\mathrm{ZnO}$, the $\mathrm{C}$ peaks of the $\mathrm{Ag}-\mathrm{ZnO} / \mathrm{GO}$ nanocomposite were shifted toward a slightly lower binding energy. In the $\mathrm{ZnO}$ sample, the presence of $C$ originated from the vacuum oil used in the pretreatment system before the XPS testing. The four peaks in the Ag- ZnO/GO sample at 282.4, 284.8, 286.1, and $288.6 \mathrm{eV}$ were ascribed to $\mathrm{Zn}-\mathrm{C}, \mathrm{C}-\mathrm{C} / \mathrm{C}=\mathrm{C}, \mathrm{Zn}-\mathrm{O}-\mathrm{C}$, and $\mathrm{C}=\mathrm{O}$, respectively $[26,27]$. The presence of abundant carbon species on the surface of the Ag- $\mathrm{ZnO} / \mathrm{GO}$ composite increased the photodegradation because it facilitated the 

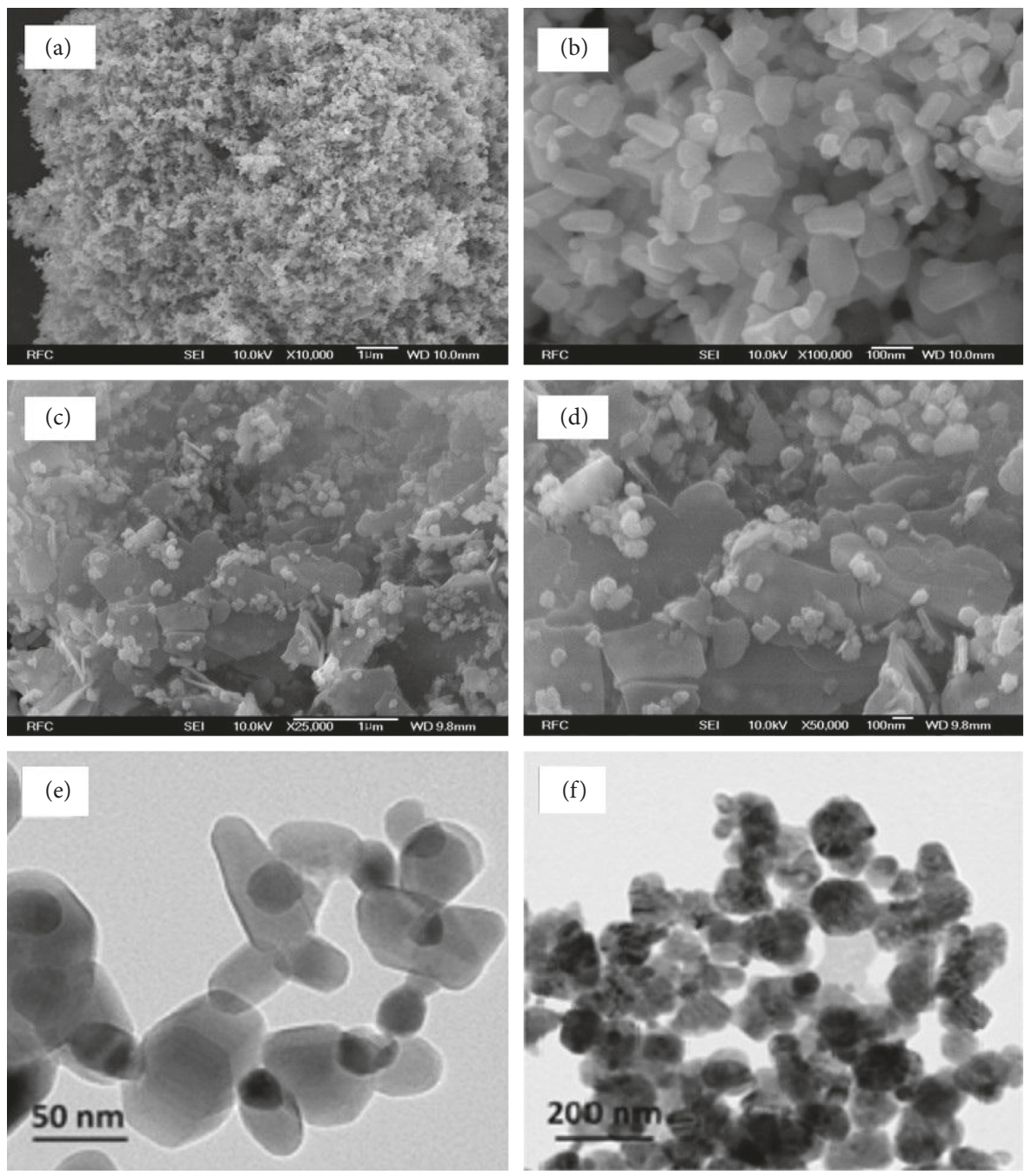

FIGURE 2: FE-SEM and TEM analyses of synthesized materials.

contact with organic pollutant molecules. The high resolution spectra of the strong O1s peak (Figure 4(c)) at $531.3 \mathrm{eV}$ in the $\mathrm{ZnO}$ sample was due to the oxygen in the $\mathrm{ZnO}$ crystal lattice (Zn-O bonds) [28, 29]. Two O1s peaks at 531.5 and $531.8 \mathrm{eV}$ in the $\mathrm{Ag}-\mathrm{ZnO} / \mathrm{GO}$ composite sample revealed the presence of surface oxygen complexes in the carbon phase [21, 28]. These oxygen-containing groups increased the photocatalytic activities due to their involvement in the production of active radicals, which play an important role in the photodegradation process. The $\mathrm{Ag} 3 \mathrm{~d}$ XPS peaks of $\mathrm{Ag}-\mathrm{ZnO} / \mathrm{GO}$, shown in Figure 4(d) located at 367.7 and $374.0 \mathrm{eV}$, were ascribed to $\mathrm{Ag} 3 \mathrm{~d}_{5 / 2}$ and $\mathrm{Ag} 3 \mathrm{~d}_{3 / 2}$, respectively $[30,31]$. The XPS results were in good agreement with the aforementioned XRD and EDS results. These observations in Figure 4 further confirmed the successful preparation of $\mathrm{Ag}-\mathrm{ZnO} / \mathrm{GO}$ nanoparticles and viability of $\mathrm{Ag}-\mathrm{ZnO} / \mathrm{GO}$ as a superior nanocomposite material.

3.1.4. UV-VIS Reflectance Spectra and Band Gap. The optical absorption properties of the synthesized nanomaterials were investigated by UV-VIS reflectance spectra (Figure 5). The doping activity induced a shift from the UV light absorption of $\mathrm{ZnO}$ to the visible light absorption of $\mathrm{Ag}-\mathrm{ZnO} /$ $\mathrm{GO}$. The optical band gaps of the synthesized materials were calculated by using the following Tauc equation:

$$
\alpha h v=A\left(h v-E_{\mathrm{g}}\right)^{n},
$$

where $\alpha$ is the absorption coefficient, $E_{\mathrm{g}}$ is the band gap, $A$ is a constant, and $n$ is an index that characterizes the optical absorption process (for direct band gap semiconductor material $n=1 / 2$ ). By extrapolating the linear region of the plot $(\alpha h v)^{2}$ vs. $h v$, the band gap could be estimated. The band gap values for $\mathrm{ZnO}$ and $\mathrm{Ag}-\mathrm{ZnO} / \mathrm{GO}$ are given in Figure 5 . Band gap of $\mathrm{Ag}-\mathrm{ZnO} / \mathrm{GO}(2.92 \mathrm{eV})$ is smaller than that of synthesized $\mathrm{ZnO}(3.15 \mathrm{eV})$. This decreased band gap may have been due to the introduction of silver and carbon as dopants in the $\mathrm{ZnO}$ lattice. Similar phenomena have been observed in $\mathrm{ZnO}$-based material systems in other studies $[19,32,33]$.

3.1.5. BET Surface Area. The specific surface area of the synthesized materials was measured using the BET method with $\mathrm{N}_{2}$ adsorption-desorption (Figure 6). The identified surface area of Ag- $\mathrm{ZnO} / \mathrm{GO}$ was almost 3.6 times larger than 


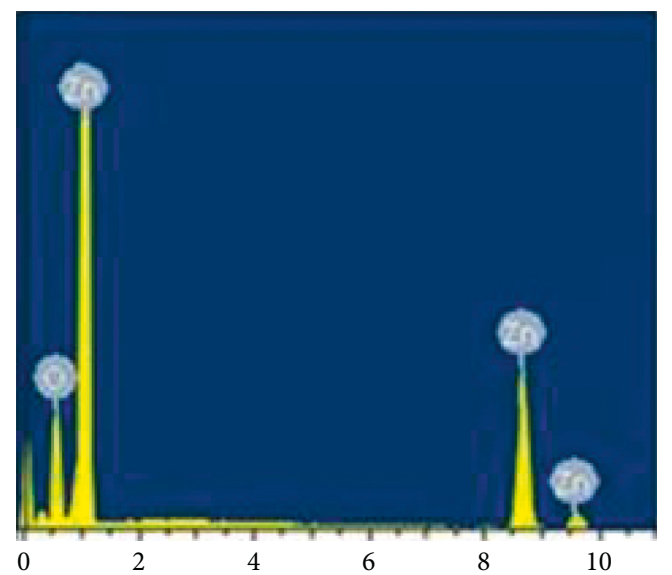

Full scale 13140 cts Cursor: $0.000 \mathrm{keV}$

(a)

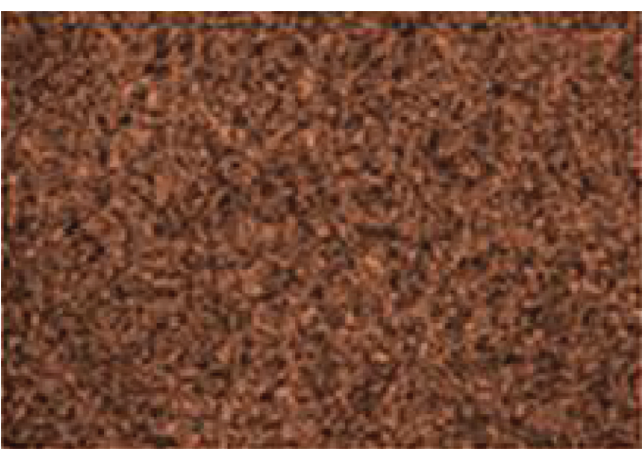

C Kal

(c)

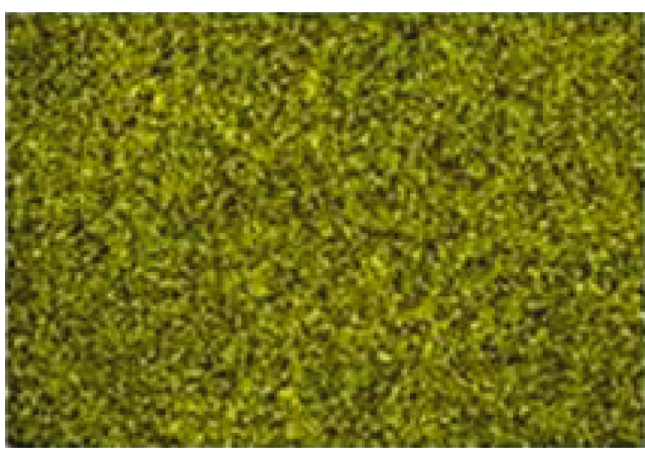

Zn Kal

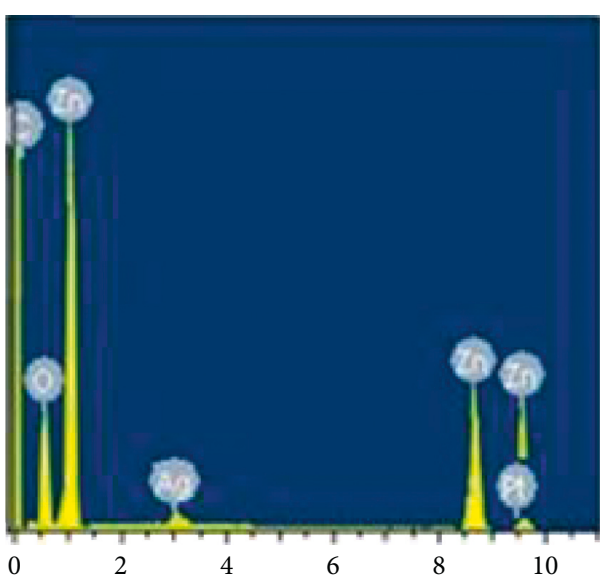

Full scale 13140 cts Cursor: $0.000 \mathrm{keV}$

(b)

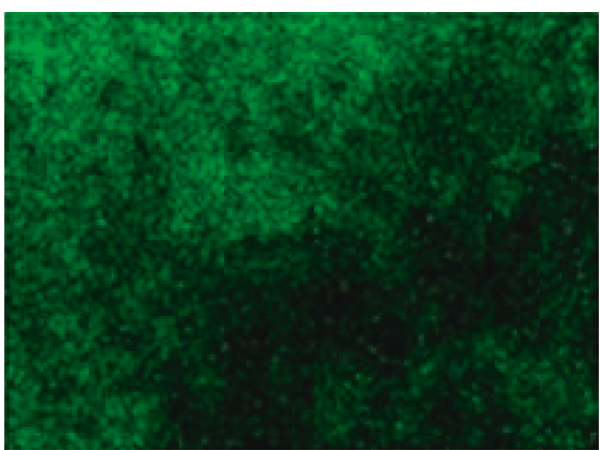

$\mathrm{O} \mathrm{Kal}$

(d)

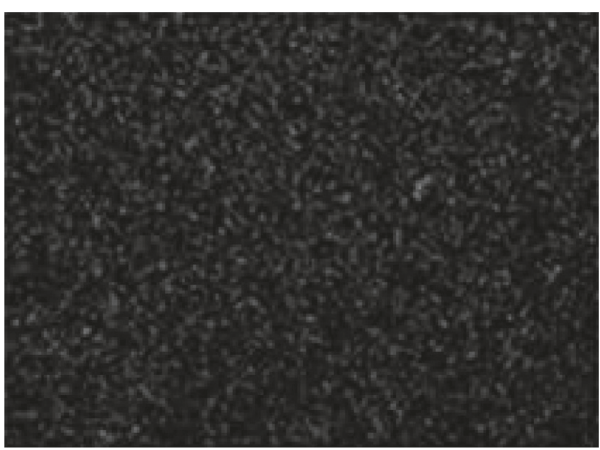

Ag La1

(e)

(f)

FIGURE 3: EDS and mapping analyses of synthesized materials.

that of $\mathrm{ZnO}$. With $\mathrm{Ag}-\mathrm{ZnO} / \mathrm{GO}$ present in a dark condition, pollutant adsorption is mainly assisted by the increased specific surface area $\left(S_{\mathrm{BET}}\right)$. In general, graphene has a very high specific surface area [34], and thus, it could provide a high adsorption capacity. GO, the oxidized form of graphene, contains oxygen functional groups on its surface that can become adsorption sites. Therefore, the enhanced degradation capacity under visible light can be attributed to the adsorption power of GO combined as a semiconductor or adsorption substrate $[35,36]$. In addition, the increased pore size of $\mathrm{Ag}-\mathrm{ZnO} / \mathrm{GO}$ nanocomposite could lead to the increases in adsorption efficiency.
3.1.6. PL Spectra. The PL spectra of as-prepared $\mathrm{ZnO}$ and $\mathrm{Ag}-\mathrm{ZnO} / \mathrm{GO}$ at room temperature are presented in Figure 7. As observed, the PL intensities of the samples increase in the following order: $\mathrm{Ag}-\mathrm{ZnO} / \mathrm{GO}$ and $\mathrm{ZnO}$. The PL intensity of the composite sample is weaker as compared with that of the $\mathrm{ZnO}$ sample, indicating that the fluorescence of the composite is quenched more efficiently than that of $\mathrm{ZnO}$. It also indicated that the incorporation of $\mathrm{ZnO}$ with $\mathrm{Ag}$ and $\mathrm{GO}$ can improve the separation of photoinduced electrons and holes. Thus, there is a high agreement with the order of $\mathrm{Pl}$ intensities when compared with the result from the removal experiments, and the recombination process can be 

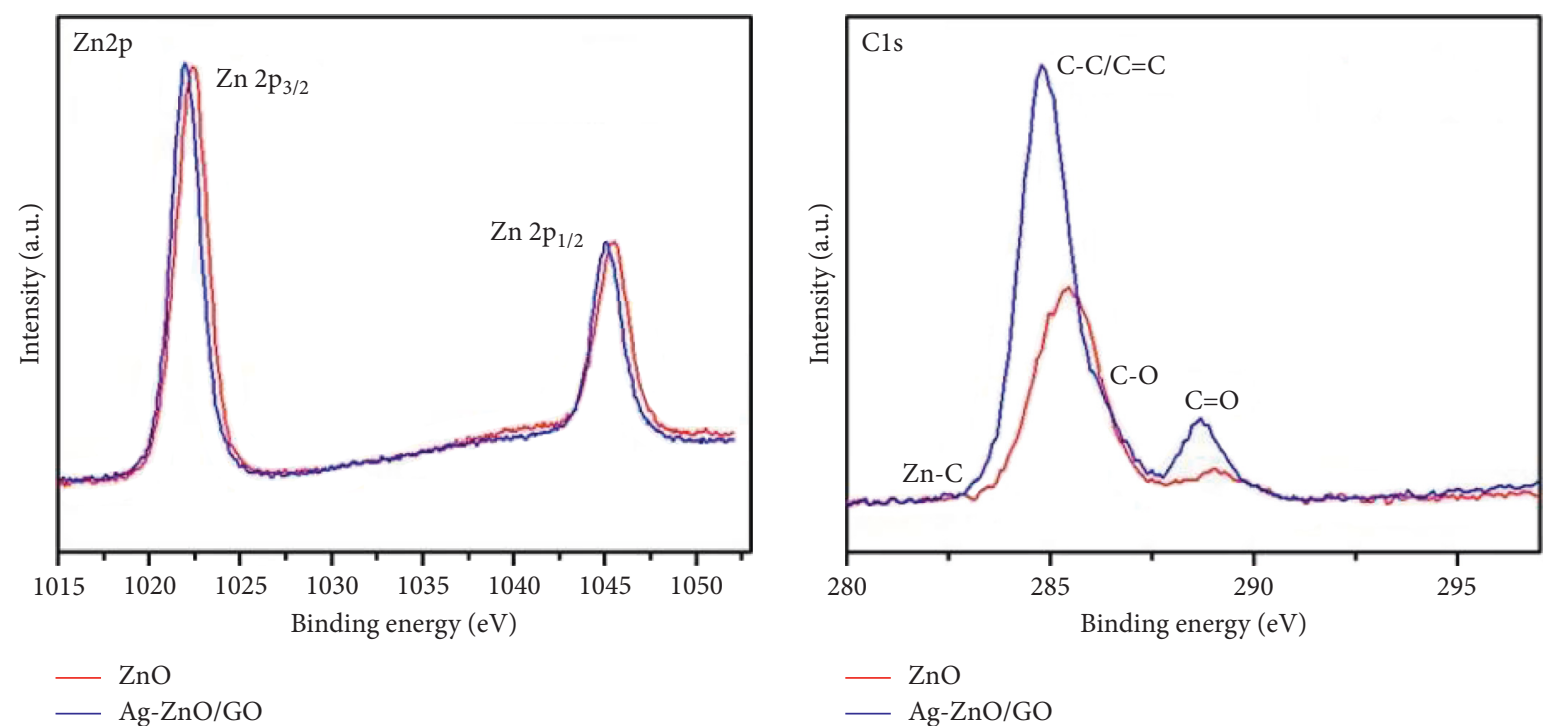

(a)

(b)
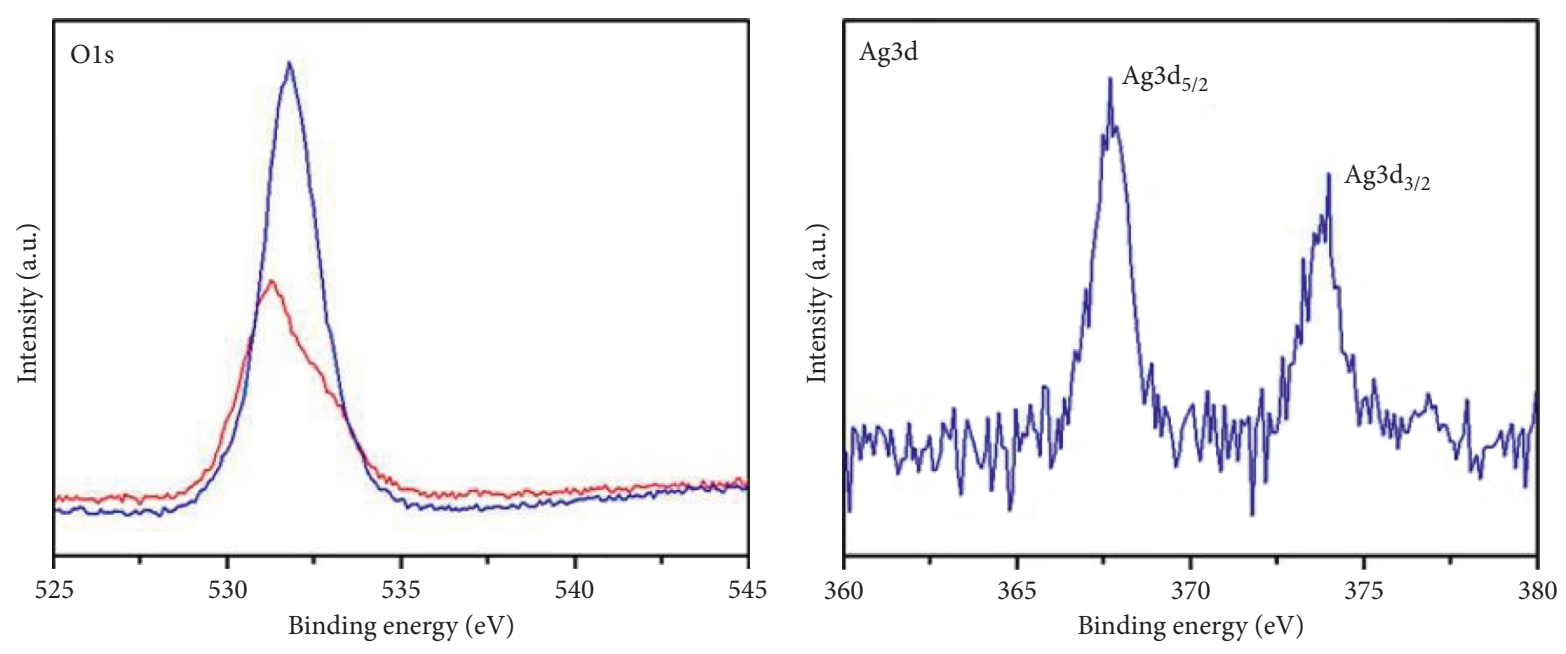

- $\mathrm{ZnO}$

- Ag-ZnO/GO

(c)

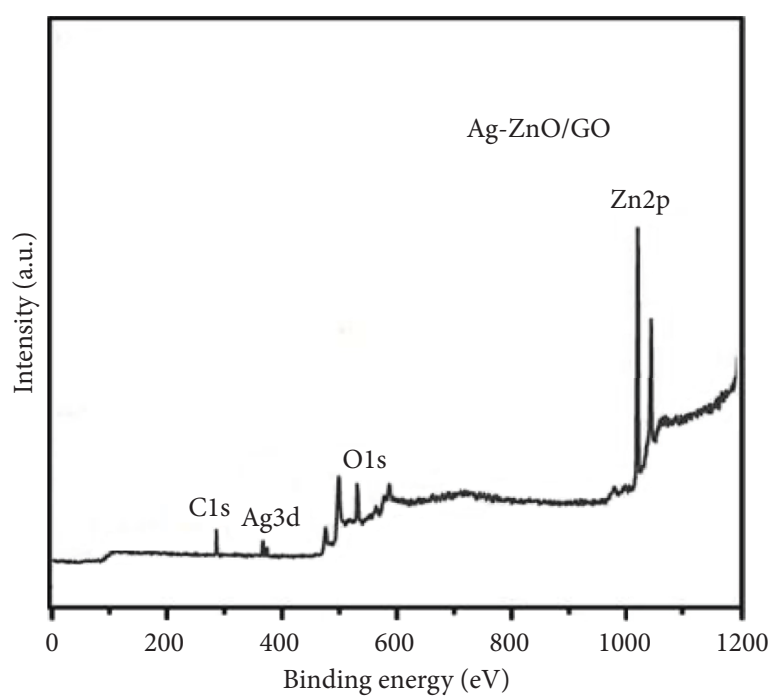

(e)

FIGURE 4: XPS analyses of synthesized materials. 


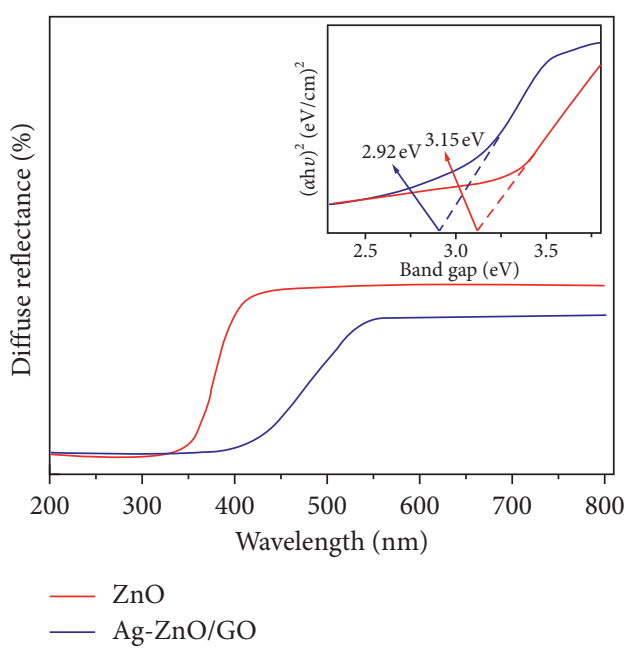

(a)

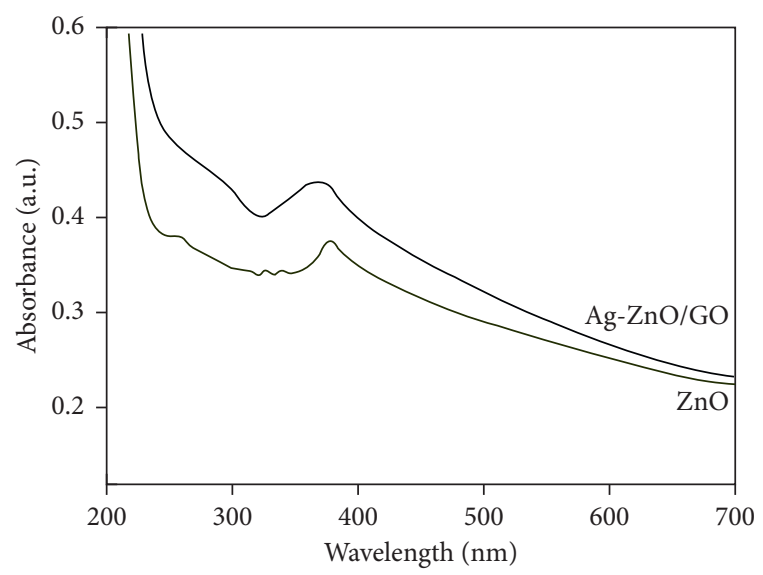

(b)

FIGURE 5: UV-VIS reflectance spectra and band gap of synthesized materials.

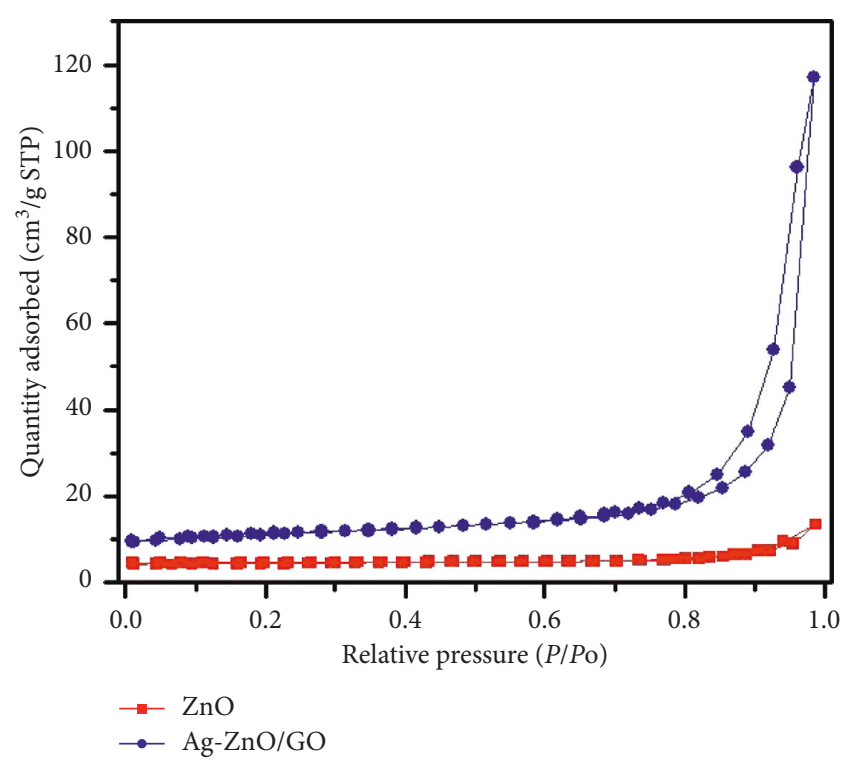

FIgURE 6: BET analysis data of synthesized materials.

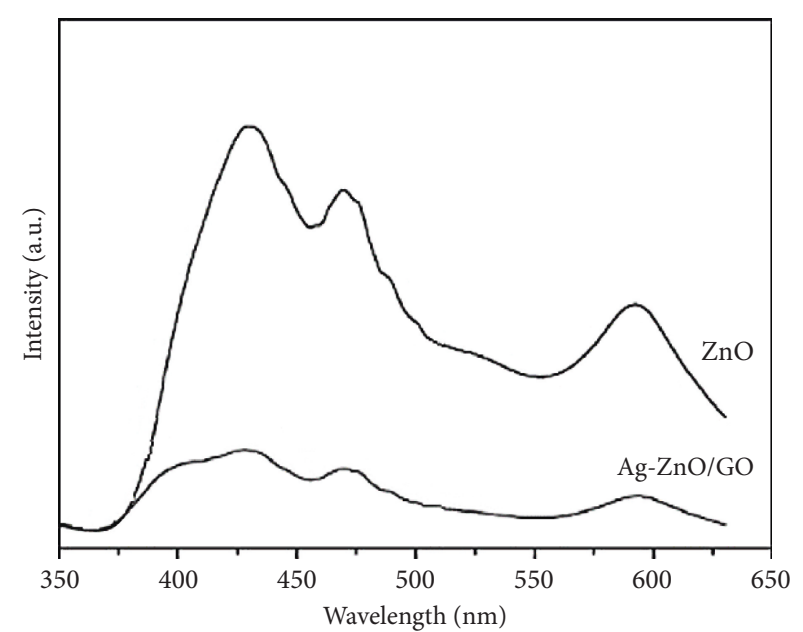

FIGURE 7: PL spectra of synthesized materials.

significantly suppressed through the combination of $\mathrm{ZnO}$ with $\mathrm{Ag}$ and GO.

3.2. Removal of MB Dye Using Synthesized Materials. It is commonly accepted that most dyes are resistant to biodegradation and direct photolysis, and many $\mathrm{N}$-containing dyes such as $\mathrm{MB}$ undergo natural reductive anaerobic degradation to yield potentially carcinogenic aromatic amines [31]. In this study, therefore, MB was chosen as a model contaminant to evaluate the photocatalytic activity of the synthesized photocatalysts.

Figures 8(a) and 8(b) show the UV-Vis absorption spectrum and removal efficiency of MB degraded by using synthesized materials under dark and light (visible and UV) irradiation conditions, respectively. $\mathrm{ZnO}$ did not show any significant adsorption of $\mathrm{MB}$, when the addition of $\mathrm{Ag}-\mathrm{ZnO} / \mathrm{GO}$ into the $\mathrm{MB}$ solution without any light source afforded an MB removal efficiency of around $20 \%$. After the adsorption, visible light or UV light was directed at the MB removal system containing $\mathrm{Ag}-\mathrm{ZnO} / \mathrm{GO}$ added into $\mathrm{MB}$ solution as a photocatalyst. The addition of $\mathrm{Ag}-\mathrm{ZnO} / \mathrm{GO}$ into the $\mathrm{MB}$ solution under visible light and UV light irradiation increased the $\mathrm{MB}$ removal efficiency after $3 \mathrm{~h}$ by up to $85 \%$ and $99 \%$, respectively. The comparison of the light absorption results between the dark and light irradiation conditions clearly demonstrated that most of the $\mathrm{MB}$ removal effects were due to photocatalytic degradation by the $\mathrm{Ag}-\mathrm{ZnO} / \mathrm{GO}$ nanocomposite. Under visible light, $\mathrm{MB}$ removal was significantly increased by $\mathrm{Ag}-\mathrm{ZnO} / \mathrm{GO}$ because of the combination effects of the adsorption and photocatalytic degradation. Under UV conditions, removal efficiency reached up to $99 \%$ because of the high photon energy in UV light, and so photodegradation could occur more strongly than under the visible light. The photocatalytic activity by $\mathrm{Ag}-\mathrm{ZnO} / \mathrm{GO}$ under visible light is explained in the mechanism section.

To clarify the role of photogenerated radical species in the removal process, different scavengers were used. It is observed from the scavenger tests' result that the degradation level of $\mathrm{MB}$ was significantly inhibited when tert-butyl 


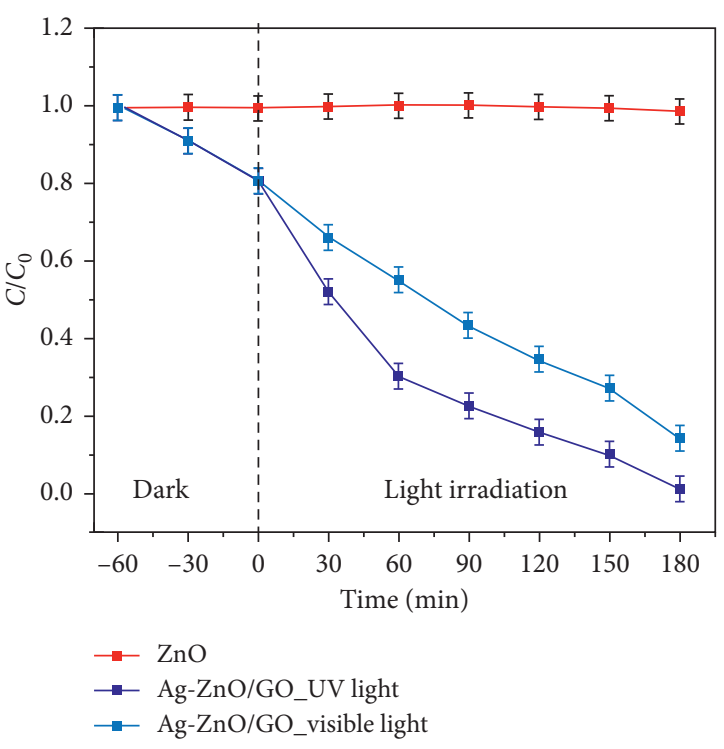

(a)

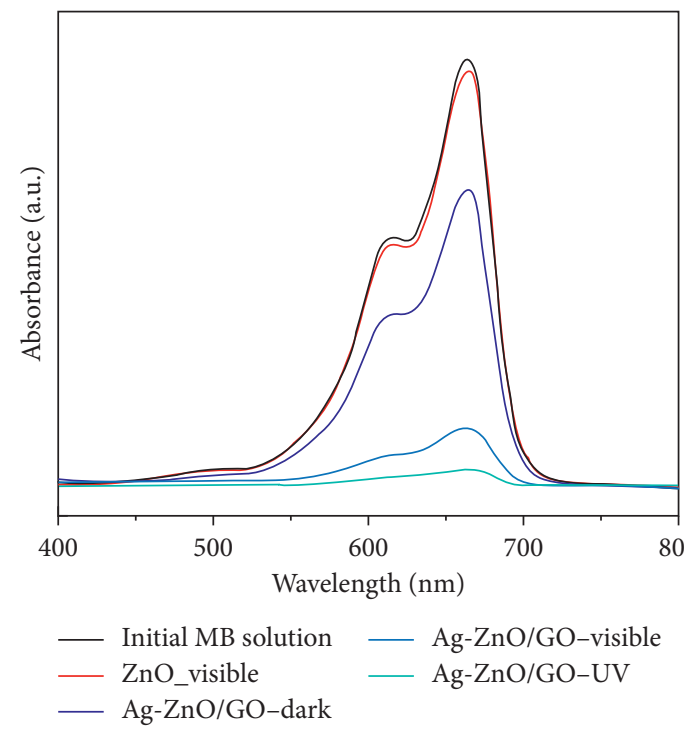

(b)

Figure 8: Removal of MB by using synthesized materials.

alcohol and ammonium oxalate were added. Thus, it is clear that most of the reactive radicals responsible for catalytic activity are found to be $\mathrm{OH}^{\bullet}$ and photogenerated holes (Figure 9).

Synthesized composite material have higher surface area and greater numbers of active sites as compared with $\mathrm{ZnO}$, where the photogenerated charge carriers react with absorbed molecules to form hydroxyl and superoxide radicals. A set of experiments was carried out in order to check the reusability and stability of the composite catalysts. The photodegradation experiment was duplicated eight times after the centrifugation and cleaning process. As shown in Figure 10, the photocatalytic activities were almost stable in the first 4 cycles. From the $5^{\text {th }}$ cycle, the removal of MB was decreased; it might be due to the loss of adsorption properties after several centrifugation and cleaning process. The particles readily form aggregates, leading to the loss of the

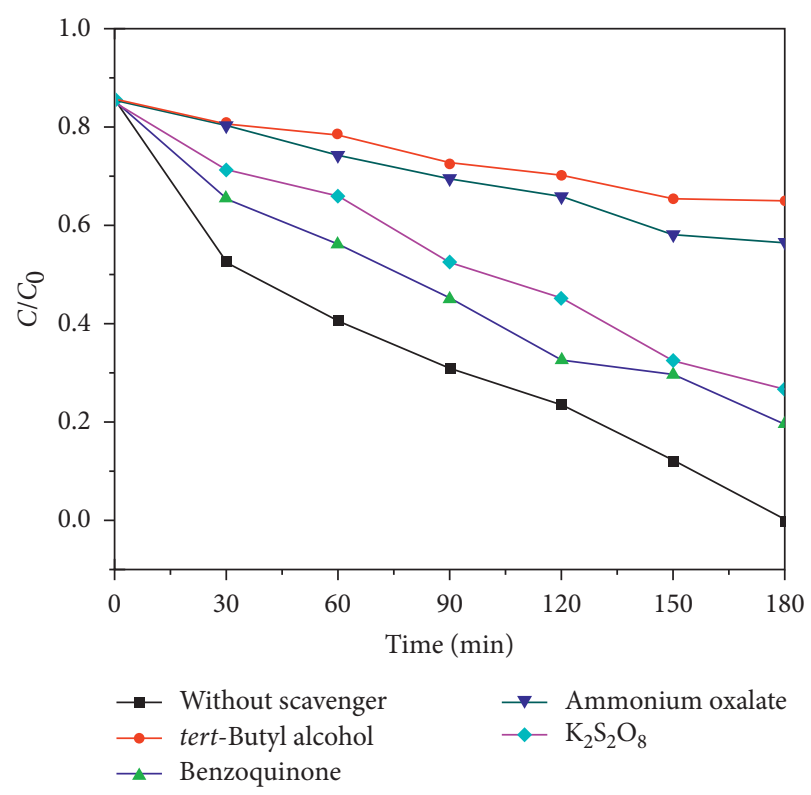

FIGURE 9: Evaluation of reactive radical species using various scavengers for photocatalytic degradation of $\mathrm{MB}$ by using $\mathrm{Ag}-\mathrm{ZnO} / \mathrm{GO}$.

original structure and active sites, thus decreasing the photocatalytic efficiency.

3.3. Effect of Initial Process Parameter. $\mathrm{pH}$ of the solution has been reported as one of the most important factors affecting the removal efficiency of organic pollutants by photocatalytic processes in an aqueous solution [37, 38]. Interpreting the $\mathrm{pH}$ effects on the $\mathrm{MB}$ dye removal process is a difficult task because it is affected by multiple factors. The effect of $\mathrm{pH}$ on the removal of $\mathrm{MB}$ dye was investigated in the $\mathrm{pH}$ range 3 to 12 . The $\mathrm{pH}$ of the point of zero charge $(\mathrm{pH}$ pzc) of $\mathrm{ZnO}$ was about 8.6 [39]. At $\mathrm{pH}$ above $\mathrm{pH}$ pzc, the surface of the $\mathrm{ZnO}$ particles was mostly positively charged. As the solution $\mathrm{pH}$ increases from the acidic range up to $\mathrm{pH}$ pzc of $\mathrm{ZnO}(\mathrm{pH}<8.6)$, the decreased $\mathrm{H}_{3} \mathrm{O}^{+}$concentration produces less repulsion of $\mathrm{Ag}-\mathrm{ZnO} / \mathrm{GO}$ with the positively charged $\mathrm{MB}$ molecules, resulting in increased adsorption of $\mathrm{MB}$. As the solution $\mathrm{pH}$ further increases above pzc $(\mathrm{pH}>8.6)$, the increased $\mathrm{OH}^{-}$produces more electron repulsion of $\mathrm{Ag}-\mathrm{ZnO} / \mathrm{GO}$ with negatively charged $\mathrm{MB}$ molecules, leading to less adsorption. Therefore, $\mathrm{pH} 8.5-9$ was chosen as the optimal $\mathrm{pH}$ for $\mathrm{MB}$ adsorption (Figure 11(a)).

Figure 11(b) shows the effects of different $\mathrm{Ag}-\mathrm{ZnO} / \mathrm{GO}$ loadings on the $\mathrm{MB}$ removal process under visible light irradiation. As the dosage of $\mathrm{Ag}-\mathrm{ZnO} / \mathrm{GO}$ increased up to $1.0 \mathrm{~g} / \mathrm{L}$, the MB removal effect also increased. The increased Ag-ZnO/GO dosage led to more active sites for adsorption and thus more moiety availability for photocatalytic degradation of $\mathrm{MB}$ molecules. However, even the MB removal efficiency decreased as the dosage loading was increased above $1 \mathrm{~g} / \mathrm{L}$. At higher dosages, there was excessive increase in the amount of suspended Ag-ZnO/GO, with excessive addition, disturbing the penetration of visible light into the reaction system. This also led to reduction in the generation 


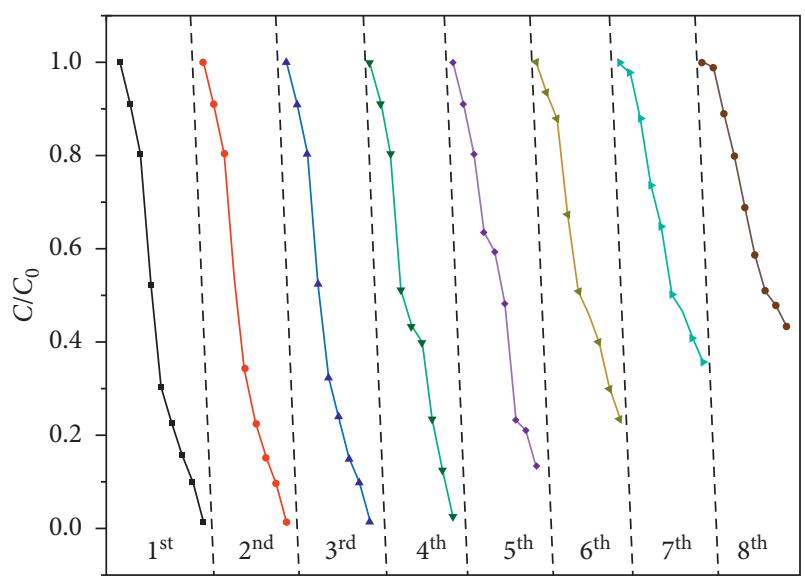

FIGURE 10: Reusability of the synthesized composite material.

of the electron-hole pairs and subsequent reduction in the production of oxy-radicals and hydroxyl radicals [40]. Furthermore, excessive photocatalyst dosage increases the pollutant removal costs. Hence, $1 \mathrm{~g} / \mathrm{L}$ was determined to be the optimum Ag- $\mathrm{ZnO} / \mathrm{GO}$ dosage.

Different initial $\mathrm{MB}$ solution concentrations, ranging from $1 \mathrm{mg} / \mathrm{L}$ to $25 \mathrm{mg} / \mathrm{L}$, were used to evaluate the $\mathrm{MB}$ removal effect by Ag- $\mathrm{ZnO} / \mathrm{GO}$ (Figure 11(c)). The $\mathrm{MB}$ removal efficiency decreased when the initial MB concentration was more than $15 \mathrm{mg} / \mathrm{L}$ within $3 \mathrm{~h}$ of irradiation. When the MB concentration was beyond the limit of $15 \mathrm{mg}$ / $\mathrm{L}$, the MB molecules adsorbed on the adsorbent/photocatalyst surface repulsed further $\mathrm{MB}$ molecules from approaching the adsorbent/photocatalyst, thereby decreasing $\mathrm{MB}$ removal. In addition, a high initial $\mathrm{MB}$ concentration hindered visible light penetration due to increased turbidity, as explained in the previous section, which decreased the light irradiation effect for photocatalytic degradation of MB [41, 42].

3.4. Photocatalytic Mechanism. Three mechanisms proposed to explain the increased photocatalytic degradation of $\mathrm{MB}$ dye by $\mathrm{Ag}-\mathrm{ZnO} / \mathrm{GO}$ under visible light irradiation are schematically shown in Figure 12.

The first proposed mechanism for the increased $\mathrm{MB}$ removal is associated with GO addition to the photocatalytic system (Figure 12(a)). GO was used as a better substrate for the photocatalytic reaction by increasing the surface area of the photocatalyst. Moreover, the photocatalytic degradation efficiency of $\mathrm{MB}$ by $\mathrm{Ag}-\mathrm{ZnO} / \mathrm{GO}$ was improved by combining it with a zero band gap semiconductor, GO $[43,44]$. Some previous studies have reported that $\mathrm{GO}$ can also enhance the photocatalytic ability of $\mathrm{ZnO}$ under visible light irradiation due to resonance effects, including the increased surface area with added GO and increased formation of $\pi-\pi^{*}$ interactions between the dye molecules [25]. The high surface area of $\mathrm{GO}$ can contribute to the effective adsorption of MB molecules on the photocatalyst surface. $\mathrm{MB}$ is a sensitive chromophore that absorbs light in a wide range of wavelengths, including the visible region $[45,46]$, and thus, MB molecules easily enter an excited status. The electrons in the excited $\mathrm{MB}^{*}$ can jump to the conduction band (CB) of $\mathrm{ZnO}$ through GO [47] and then be transferred to various Ag levels (Figures 12(b) and 12(c)). This series of excited electron transfer can minimize or delay the recombination of electrons with holes. Therefore, the excited electrons can have more delayed recombination, while simultaneously increasing the charge transfer capacity from the valence band (VB) to the $\mathrm{CB}$ of $\mathrm{ZnO}$.

The second mechanism for the enhanced photocatalytic degradation of $\mathrm{MB}$ could be due to the Ag doping effect into the $\mathrm{ZnO}$ crystal lattice (Figure 12(c)). It is well known that band gap is a region of energy with no allowed states. The density of states versus energy depends on the chemical composition of the material, and the state density distribution will be changed if the chemical composition is changed. In this case, Ag dopant is the impurity, so the chemical composition was changed by doping. When the doping density is high enough, the dopant states generate a band. If this band is very close to the valence or conduction band edge, the band gap will decrease. The electrons transferred to the $\mathrm{CB}$ of $\mathrm{ZnO}$ tend to be transferred to $\mathrm{Ag}$ at that time, which prevents delay of the recombination of the excited electrons and holes. Addition of Ag led to the formation of "stairs" that allow the excited electrons to move easily to higher energy levels with visible light irradiation rather than directly moving down to the holes. The minimized recombination of the excited electrons in the $\mathrm{CB}$ with the holes in the VB can increase the opportunity for the production of oxy-radicals by reaction with $\mathrm{O}_{2}$ molecules, leading to the oxidative degradation of $\mathrm{MB}$ molecules.

The third proposed mechanism is based on the narrowed band gap of the semiconductor (Figure 12(b)). The major limitation of $\mathrm{ZnO}$ is its restriction to $\mathrm{UV}$ light irradiation because of its wide band gap. This weakness was improved through $\mathrm{Ag}$ doping into the $\mathrm{ZnO}$ lattice by narrowing the band gap. Dotted green lines (Figure 12(c)) represent a new band gap for $\mathrm{ZnO}$, which was narrowed by the interaction between $\mathrm{ZnO}, \mathrm{Ag}$, and $\mathrm{GO}$ during the synthesis of the Ag$\mathrm{ZnO} / \mathrm{GO}$ nanocomposite [48]. The major oxidative and reductive processes for the photodegradation of $\mathrm{MB}$ by using $\mathrm{Ag}-\mathrm{ZnO} / \mathrm{GO}$ with a narrowed band gap under visible light illumination can be explained as shown in equation (3) to (11). 




(a)

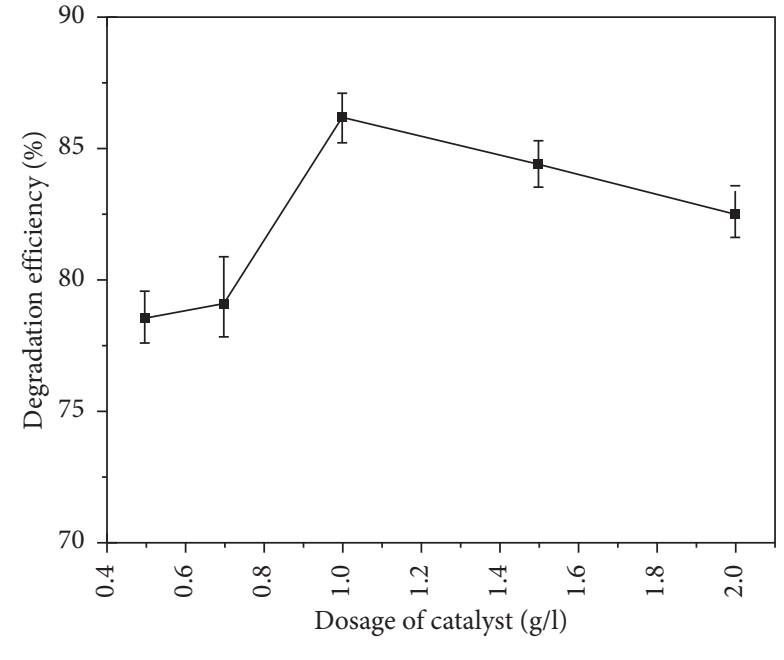

(b)

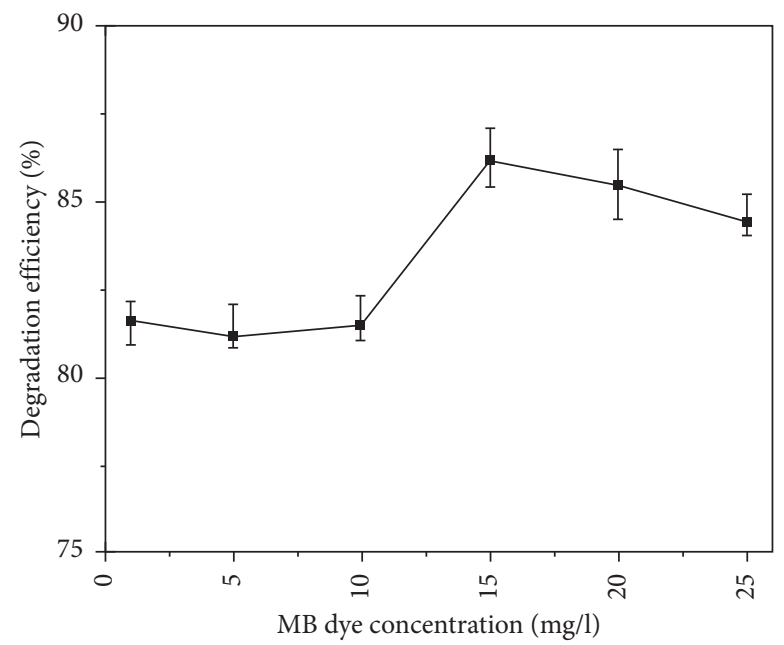

(c)

FIgURE 11: Effect of the initial parameter on the MB removal efficiency.

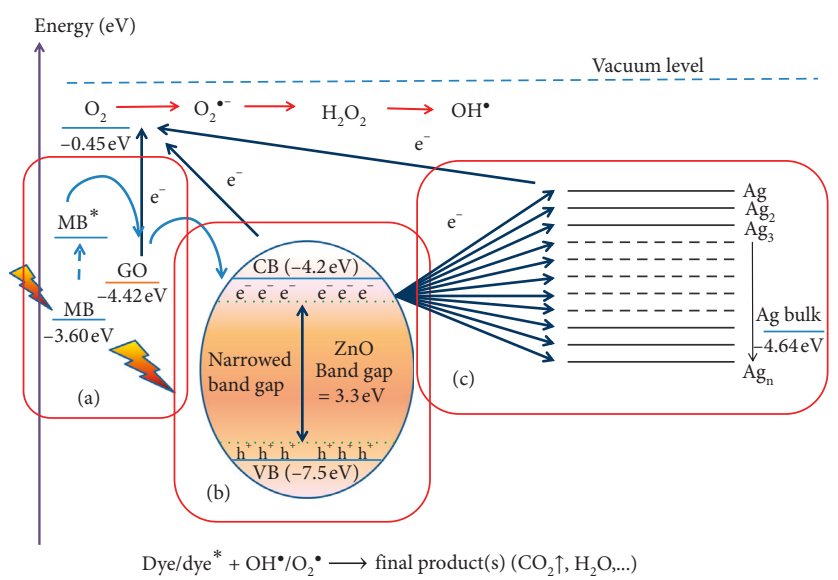

Figure 12: Proposed mechanism for MB removal using synthesized material. 
TABLE 2: Comparison between previous and current studies for MB removal using photocatalytic degradation.

\begin{tabular}{|c|c|c|c|c|c|c|c|c|}
\hline Photocatalyst & Chemical ingredients & $\begin{array}{l}\text { Calcination } \\
\text { temperature }\end{array}$ & $\begin{array}{l}\text { Light } \\
\text { source }\end{array}$ & Adsorption & Photocatalysis & $\begin{array}{l}\text { Total } \\
\text { removal }\end{array}$ & Remark & Ref. \\
\hline $\begin{array}{l}\text { Sulphonated } \\
\text { GO-ZnO-Ag }\end{array}$ & $\begin{array}{c}\mathrm{Zn}\left(\mathrm{CH}_{3} \mathrm{COO}\right)_{2} \cdot 2 \mathrm{H}_{2} \mathrm{O} \\
\mathrm{HMTA}, \mathrm{EG}, \mathrm{AGNO} \mathrm{H}_{3}, \mathrm{HCl} \\
\mathrm{ClCH}_{2} \mathrm{CH}_{2} \mathrm{SO}_{3} \mathrm{H}, \mathrm{AgNO}_{3} \\
\mathrm{NaNO}_{3}, \mathrm{KMnO}_{4}, \mathrm{H}_{2} \mathrm{O}_{2} \\
\mathrm{H}_{2} \mathrm{SO}_{4}\end{array}$ & 160 & Visible & $20 \%$ & $78 \%$ & $98 \%$ & $\begin{array}{l}\text { Sulfonated GO high } \\
\text { calcination } \\
\text { temperature }\end{array}$ & [13] \\
\hline $\begin{array}{l}\mathrm{Ag}-\mathrm{ZnO} / \\
\mathrm{RGO}\end{array}$ & $\begin{array}{l}\mathrm{GO} \text {, bis-hexamethylene } \\
\text { triamine, } \mathrm{Zn}\left(\mathrm{NO}_{3}\right)_{2} \cdot 6 \mathrm{H}_{2} \mathrm{O} \\
\mathrm{AgNO}_{3} \text {, ethanol }\end{array}$ & $\begin{array}{l}140, \text { in } \\
\text { autoclave }\end{array}$ & Visible & & Not separated & $65 \%$ & $\begin{array}{l}\text { Reduced GO high } \\
\text { calcination } \\
\text { temperature in } \\
\text { autoclave }\end{array}$ & [15] \\
\hline $\begin{array}{l}\text { Graphene- } \\
\mathrm{Ag} / \mathrm{ZnO}\end{array}$ & $\begin{array}{c}\text { Graphene, EG, } \mathrm{CH}_{3} \mathrm{COOAg}, \\
\mathrm{Zn}\left(\mathrm{CH}_{3} \mathrm{COO}\right)_{2} \cdot 2 \mathrm{H}_{2} \mathrm{O} \\
\mathrm{NaOH}\end{array}$ & 160 & Visible & $28.6 \%$ & $65.6 \%$ & $94.4 \%$ & $\begin{array}{c}\text { Graphene expensive } \\
\text { high calcination } \\
\text { temperature }\end{array}$ & {$[8]$} \\
\hline $\mathrm{Ag} / \mathrm{ZnO} / \mathrm{GO}$ & $\begin{array}{c}\text { Graphite oxide, } \mathrm{ZnO}, \\
\mathrm{AgNO}_{3}\end{array}$ & 55 & UV & & Not separated & $98 \%$ & $\begin{array}{l}\text { GO UV light high } \\
\text { energy safety issue }\end{array}$ & {$[16]$} \\
\hline \multirow{2}{*}{$\mathrm{Ag}-\mathrm{ZnO} / \mathrm{GO}$} & \multirow{2}{*}{$\begin{array}{c}\text { Graphene oxide, } \mathrm{AgNO}_{3} \\
\mathrm{ZnSO}_{4} \cdot 7 \mathrm{H}_{2} \mathrm{O}, \mathrm{C}_{6} \mathrm{H}_{6} \mathrm{O}_{6}\end{array}$} & \multirow{2}{*}{70} & Visible & $25 \%$ & $60 \%$ & $85 \%$ & $\begin{array}{l}\text { GO visible light low } \\
\text { energy high safety }\end{array}$ & $\begin{array}{l}\text { This } \\
\text { study }\end{array}$ \\
\hline & & & UV & $25 \%$ & $74 \%$ & $99 \%$ & $\begin{array}{l}\text { UV light high energy } \\
\text { safety issue }\end{array}$ & $\begin{array}{l}\text { This } \\
\text { study }\end{array}$ \\
\hline
\end{tabular}

(I) Oxidative reactions with holes

$$
\begin{aligned}
\mathrm{h}^{+}+\mathrm{H}_{2} \mathrm{O} & \longrightarrow \mathrm{H}^{+}+\mathrm{OH}^{\bullet} \\
2 \mathrm{~h}^{+}+2 \mathrm{H}_{2} \mathrm{O} & \longrightarrow 2 \mathrm{H}^{+}+\mathrm{H}_{2} \mathrm{O}_{2} \\
\mathrm{H}_{2} \mathrm{O}_{2} & \longrightarrow \mathrm{HO}^{\bullet}+{ }^{\bullet} \mathrm{OH}
\end{aligned}
$$

(II) Reduction reaction with $\mathrm{O}_{2}$

$$
\begin{aligned}
2 \mathrm{e}^{-}+\mathrm{O}_{2} & \longrightarrow{ }^{\bullet} \mathrm{O}_{2}{ }^{-} \\
\mathrm{O}_{2}{ }^{-}+2 \mathrm{H}^{+} & \longrightarrow \mathrm{H}_{2} \mathrm{O}_{2}+\mathrm{O}_{2} \\
\mathrm{H}_{2} \mathrm{O}_{2} & \longrightarrow \mathrm{HO}^{\bullet}+{ }^{\bullet} \mathrm{OH}
\end{aligned}
$$

(III) Photocatalytic oxidation with oxy-radicals Dye/Dye ${ }^{*}+{ }^{\bullet} \mathrm{OH} \longrightarrow$ final products $\left(\mathrm{CO}_{2}, \mathrm{H}_{2} \mathrm{O}, \ldots\right)$

$$
\text { Dye/Dye }{ }^{*}+{ }^{\bullet} \mathrm{O}_{2}{ }^{-} \longrightarrow \text { final products }\left(\mathrm{CO}_{2}, \mathrm{H}_{2} \mathrm{O}, \ldots\right)
$$

3.5. Energy and Cost Issue. Nowadays, the demand and market for the use of nanoparticles or nanocatalysts in pollutant removal are increasing. As discussed above, $\mathrm{ZnO}$ nanoparticle is one of the most promising materials for wastewater treatment. Performance of $\mathrm{ZnO}$ can be enhanced by adding some ingredients to make better nanocomposite. The methods currently developed for making better $\mathrm{ZnO}$ nanomaterials mainly consist of sol-gel template and hydrothermal methods. However, the requirement of high crystallinity is a major problem in $\mathrm{ZnO}$ synthesis. With the sol-gel method, calcination of gels or thermal annealing of emulsions is therefore required to induce crystallization of the nanoparticle, and thus, normally a high temperature of more than $200^{\circ} \mathrm{C}$ is required. Hydrothermal methods are directly carried out at slightly lower temperatures than solgel methods (but not less than $120^{\circ} \mathrm{C}$ ). However, nanocrystals formed with hydrothermal methods agglomerate and thus are insoluble in most solvents, and thus, some stabilizing agents are required to prevent agglomeration. Their characteristics from previous relevant study outcomes are summarized in Table 2 with comparisons.

The search for a simple and economic synthesis method to derive nanoparticles with good size and shape at low temperature is still an open challenge. The ability to produce nanomaterials at lower temperatures is needed for the purpose of saving energy and increasing safety for large-scale production. In this study, we demonstrate that it is possible to cost effectively produce nanomaterials at low temperature in considerable quantities, with increased safety in a wide range of applications. By adding the noble metal $\mathrm{Ag}$ as a dopant and GO as a high surface area adsorption substrate, firstly, our nanomaterial can work excellently for adsorption and also as a photocatalyst, even under visible light. Researchers have previously used UV light in their studies to irradiate the photocatalyst, and the removal efficiency of their process was very high. However, the price of a UV lamp is at least two times as high as the price of a visible lamp. Furthermore, UV waves are invisible but very harmful for human eyes. Secondly, for processing our current method, only a calcination temperature of around $70^{\circ} \mathrm{C}$ is needed without any requirements for complex instruments. From an economical view, such fabrication may offer better opportunities to significantly lower the cost of manufacturing nanomaterials, while bringing environmental advantages such as low energy consumption and reduced $\mathrm{CO}_{2}$ emissions. Thirdly, the simplicity of the synthesis procedure 
would make it safe for workers and easy to apply to industrial manufacturing.

\section{Conclusion}

Ag-ZnO/GO nanocomposite was successfully synthesized by facile aqueous solution reactions at low temperature. The MB removal efficiency increased up to $99 \%$ under the UV light and $85 \%$ under visible light. The optimum conditions for maximum removal efficiency of $\mathrm{MB}$ were $\mathrm{pH}$ 8.5-9, temperature $35^{\circ} \mathrm{C}$ and dosage $1 \mathrm{~g} / \mathrm{L}$ at $\mathrm{MB}$ concentration $15 \mathrm{mg} / \mathrm{L}$. The significant increase in photocatalytic degradation for $\mathrm{MB}$ removal exhibited by $\mathrm{Ag}-\mathrm{ZnO} / \mathrm{GO}$ was due to the combined effects of the two semiconductors, $\mathrm{ZnO}$ and $\mathrm{GO}$, and Ag doping into the $\mathrm{ZnO}$ crystal lattice. The proposed mechanism for enhanced removal includes an increase in adsorption by adding GO with a high surface area and an increase in photocatalytic activities due to improved charge transfer capacity achieved through lowering the band gap energy of $\mathrm{ZnO}$, thus minimizing the recombination of the excited electrons in the $\mathrm{CB}$ with the holes in $\mathrm{VB}$ of $\mathrm{ZnO}$, leading to higher removal rate of $\mathrm{MB}$.

\section{Data Availability}

The data used to support the findings of this study are available from the corresponding author upon request.

\section{Conflicts of Interest}

The authors declare that they have no conflicts of interest.

\section{Acknowledgments}

The authors would like to thank Vietnam Japan University Research Fund which is funded by Japan International Cooperation Agency (JICA) to full time lecturer of Vietnam Japan University (Dr. Tran Thi Viet Ha of Master's Program of Vietnam Japan University).

\section{References}

[1] M. Nasrollahzadeh, M. Atarod, B. Jaleh, and M. Gandomirouzbahani, "In situ green synthesis of $\mathrm{Ag}$ nanoparticles on graphene oxide/ $\mathrm{TiO}_{2}$ nanocomposite and their catalytic activity for the reduction of 4-nitrophenol, congo red and methylene blue," Ceramics International, vol. 42, no. 7 , pp. 8587-8596, 2016.

[2] M. Eskandari, V. Ahmadi, S. Kohnehpoushi, and M. Yousefi rad, "Improvement of $\mathrm{ZnO}$ nanorod based quantum Dot (cadmium sulfide) sensitized solar cell efficiency by aluminum doping," Physica E: Low-Dimensional Systems and Nanostructures, vol. 66, pp. 275-282, 2015.

[3] K. Takahashi, A. Yoshikawa, and S. Adarsh, Wide Bandgap Semiconductors: Fundamental Properties and Modern Photonic and Electronic Devices, Springer, Heidelberg, Germany, 2007.

[4] F. Ghorbani Shahna, A. Bahrami, I. Alimohammadi et al., "Chlorobenzene degeradation by non-thermal plasma combined with $\mathrm{EG}-\mathrm{TiO}_{2} / \mathrm{ZnO}$ as a photocatalyst: effect of photocatalyst on $\mathrm{CO}_{2}$ selectivity and byproducts reduction," Journal of Hazardous Materials, vol. 324, pp. 544-553, 2017.
[5] X. Li, Q. Wang, Y. Zhao, W. Wu, J. Chen, and H. Meng, "Green synthesis and photo-catalytic performances for $\mathrm{ZnO}$ reduced graphene oxide nanocomposites," Journal of Colloid and Interface Science, vol. 411, pp. 69-75, 2013.

[6] O. Yayapao, T. Thongtem, A. Phuruangrat, and S. Thongtem, "Sonochemical synthesis of Dy-doped $\mathrm{ZnO}$ nanostructures and their photocatalytic properties," Journal of Alloys and Compounds, vol. 576, pp. 72-79, 2013.

[7] L. Zhang, N. Li, H. Jiu, G. Qi, and Y. Huang, "ZnO-reduced graphene oxide nanocomposites as efficient photocatalysts for photocatalytic reduction of $\mathrm{CO}_{2}$," Ceramics International, vol. 41, no. 5, pp. 6256-6262, 2015.

[8] M. Ahmad, E. Ahmed, Z. L. Hong, N. R. Khalid, W. Ahmed, and A. Elhissi, "Graphene-Ag/ZnO nanocomposites as high performance photocatalysts under visible light irradiation," Journal of Alloys and Compounds, vol. 577, pp. 717-727, 2013.

[9] A. Omidvar, B. Jaleh, M. Nasrollahzadeh, and H. R. Dasmeh, "Fabrication, characterization and application of $\mathrm{GO} / \mathrm{Fe}_{3} \mathrm{O}_{4} / \mathrm{Pd}$ nanocomposite as a magnetically separable and reusable catalyst for the reduction of organic dyes," Chemical Engineering Research and Design, vol. 121, pp. 339-347, 2017.

[10] L.-L. Tan, W.-J. Ong, S.-P. Chai, and A. Mohamed, "Reduced graphene oxide- $\mathrm{TiO}_{2}$ nanocomposite as a promising visiblelight-active photocatalyst for the conversion of carbon dioxide," Nanoscale Research Letters, vol. 8, no. 1, pp. 1-9, 2013.

[11] P.-Q. Wang, Y. Bai, P.-Y. Luo, and J.-Y. Liu, "Graphene- $\mathrm{WO}_{3}$ nanobelt composite: elevated conduction band toward photocatalytic reduction of $\mathrm{CO}_{2}$ into hydrocarbon fuels," $\mathrm{Ca}$ talysis Communications, vol. 38, pp. 82-85, 2013.

[12] M. Nasrollahzadeh, B. Jaleh, and A. Jabbari, "Synthesis, characterization and catalytic activity of graphene oxide/ $\mathrm{ZnO}$ nanocomposites," RSC Advances, vol. 4, no. 69, pp. 36713-36720, 2014.

[13] P. Gao, K. Ng, and D. D. Sun, "Sulfonated graphene oxide$\mathrm{ZnO}$-Ag photocatalyst for fast photodegradation and disinfection under visible light," Journal of Hazardous Materials, vol. 262 , pp. 826-835, 2013.

[14] B. Jaleh and A. Jabbari, "Evaluation of reduced graphene oxide/ZnO effect on properties of PVDF nanocomposite films," Applied Surface Science, vol. 320, pp. 339-347, 2014.

[15] H. Raj Pant, B. Pant, H. Joo Kim et al., "A green and facile onepot synthesis of $\mathrm{Ag}-\mathrm{ZnO} / \mathrm{RGO}$ nanocomposite with effective photocatalytic activity for removal of organic pollutants," Ceramics International, vol. 39, no. 5, pp. 5083-5091, 2013.

[16] J. Qin, R. Li, C. Lu, Y. Jiang, H. Tang, and X. Yang, “Ag/ZnO/ graphene oxide heterostructure for the removal of rhodamine B by the synergistic adsorption-degradation effects," Ceramics International, vol. 41, no. 3, pp. 4231-4237, 2015.

[17] S. Xu, L. Fu, T. S. H. Pham, A. Yu, F. Han, and L. Chen, "Preparation of $\mathrm{ZnO}$ flower/reduced graphene oxide composite with enhanced photocatalytic performance under sunlight," Ceramics International, vol. 41, no. 3, pp. 4007-4013, 2015.

[18] L. Zhang, G. Du, B. Zhou, and L. Wang, "Green synthesis of flower-like $\mathrm{ZnO}$ decorated reduced graphene oxide composites," Ceramics International, vol. 40, no. 1, pp. 1241-1244, 2014.

[19] S. Shet, K.-S. Ahn, T. Deutsch et al., "Synthesis and characterization of band gap-reduced $\mathrm{ZnO}: \mathrm{N}$ and $\mathrm{ZnO}:(\mathrm{Al}, \mathrm{N})$ films for photoelectrochemical water splitting," Journal of Materials Research, vol. 25, no. 1, pp. 69-75, 2010.

[20] R. S. Patil, M. R. Kokate, D. V. Shinde, S. S. Kolekar, and S. H. Han, "Synthesis and enhancement of photocatalytic activities of $\mathrm{ZnO}$ by silver nanoparticles," Spectrochimica Acta Part A: Molecular and Biomolecular Spectroscopy, vol. 122, pp. 113-117, 2014. 
[21] Z. H. Ibupoto, N. Jamal, K. Khun, X. Liu, and M. Willander, “A potentiometric immunosensor based on silver nanoparticles decorated $\mathrm{ZnO}$ nanotubes, for the selective detection of d-dimer," Sensors and Actuators B: Chemical, vol. 182, pp. 104-111, 2013.

[22] Y.-W. Tseng, F.-Y. Hung, T.-S. Lui, and S.-J. Chang, "Structural and Raman properties of silver-doped $\mathrm{ZnO}$ nanorod arrays using electrically induced crystallization process," Materials Research Bulletin, vol. 64, pp. 274-278, 2015.

[23] R. Viswanath, H. S. B. Naik, Y. K. G. Somalanaik, P. K. P. Neelanjeneallu, K N. Harish, and M. C. Prabhakara, "Studies on characterization, optical absorption, and photoluminescence of yttrium doped ZnS nanoparticles," Journal of Nanotechnology, vol. 2014, Article ID 924797, 8 pages, 2014.

[24] S. W. Lu, B. I. Lee, Z. L. Wang et al., "Synthesis and photoluminescence enhancement of $\mathrm{Mn}^{2+}$-doped $\mathrm{ZnS}$ nanocrystals," Journal of Luminescence, vol. 92, no. 1-2, pp. 73-78, 2000.

[25] S. Vadivel, M. Vanitha, A. Muthukrishnaraj, and N. Balasubramanian, "Graphene oxide-BiOBr composite material as highly efficient photocatalyst for degradation of methylene blue and rhodamine-B dyes," Journal of Water Process Engineering, vol. 1, pp. 17-26, 2014.

[26] H. Ma, X. Cheng, C. Ma et al., "Characterization, and photocatalytic activity of $\mathrm{N}$-doped $\mathrm{ZnO} / \mathrm{ZnS}$ composites," International Journal of Photoenergy, vol. 2013, Article ID 625024, 8 pages, 2013.

[27] M. Ahmad, E. Ahmed, W. Ahmed, A. Elhissi, Z. L. Hong, and R. N. Khalid, "Enhancing visible light responsive photocatalytic activity by decorating $\mathrm{Mn}$-doped $\mathrm{ZnO}$ nanoparticles on graphene," Ceramics International, vol. 40, no. 7, pp. 10085-10097, 2014.

[28] K. Dai, L. Lu, C. Liang et al., "Graphene oxide modified ZnO nanorods hybrid with high reusable photocatalytic activity under UV-LED irradiation," Materials Chemistry and Physics, vol. 143, no. 3, pp. 1410-1416, 2014.

[29] Y. Ji, S.-A. Lee, A.-N. Cha et al., "Resistive switching characteristics of $\mathrm{ZnO}$-graphene quantum dots and their use as an active component of an organic memory cell with one diodeone resistor architecture," Organic Electronics, vol. 18, pp. 77-83, 2015.

[30] J. Xu, Y. Chang, Y. Zhang, S. Ma, Y. Qu, and C. Xu, "Effect of silver ions on the structure of $\mathrm{ZnO}$ and photocatalytic performance of $\mathrm{Ag} / \mathrm{ZnO}$ composites," Applied Surface Science, vol. 255, no. 5, pp. 1996-1999, 2008.

[31] J. Xu, X. Han, H. Liu, and Y. Hu, "Synthesis and optical properties of silver nanoparticles stabilized by gemini surfactant," Colloids and Surfaces A: Physicochemical and Engineering Aspects, vol. 273, no. 1-3, pp. 179-183, 2006.

[32] B. Sankara Reddy, Y. Prabhakara Reddy, S. V. Reddy, and N. K. Reddy, "Structural, optical and magnetic properties of (Fe, Ag) co-doped $\mathrm{ZnO}$ nanostructures," Advanced Materials Letters, vol. 5, pp. 199-205, 2014.

[33] R. Rahimi, J. Shokrayian, and M. Rabbani, "Photocatalytic removing of methylene blue by using of $\mathrm{Cu}$-doped $\mathrm{ZnO}$, Agdoped $\mathrm{ZnO}$ and $\mathrm{Cu}, \mathrm{Ag}$-codoped $\mathrm{ZnO}$ nanostructure," in Proceedings of the 17th International Electronic Conference on Synthetic Organic Chemistry, Basel, Switzerland, November 2013.

[34] Y. Zhu, S. Murali, W. Cai et al., "Graphene and graphene oxide: synthesis, properties, and applications," Advanced Materials, vol. 22, no. 35, pp. 3906-3924, 2010.
[35] P. Fu, Y. Luan, and X. Dai, "Preparation of activated carbon fibers supported $\mathrm{TiO}_{2}$ photocatalyst and evaluation of its photocatalytic reactivity," Journal of Molecular Catalysis A: Chemical, vol. 221, no. 1-2, pp. 81-88, 2004.

[36] H. Yoneyama and T. Torimoto, "Titanium dioxide/adsorbent hybrid photocatalysts for photodestruction of organic substances of dilute concentrations," Catalysis Today, vol. 58, no. 2-3, pp. 133-140, 2000.

[37] M. R. Hoffmann, S. T. Martin, W. Choi, and D. W. Bahnemann, "Environmental applications of semiconductor photocatalysis," Chemical Reviews, vol. 95, no. 1, pp. 69-96, 1995.

[38] L. N. Lewis, "Chemical catalysis by colloids and clusters," Chemical Reviews, vol. 93, no. 8, pp. 2693-2730, 1993.

[39] J. Wang, Z. Jiang, Z. Zhang et al., "Sonocatalytic degradation of acid red $\mathrm{B}$ and rhodamine $\mathrm{B}$ catalyzed by nano-sized $\mathrm{ZnO}$ powder under ultrasonic irradiation," Ultrasonics Sonochemistry, vol. 15, no. 5, pp. 768-774, 2008.

[40] M. Pera-Titus, V. Garćia-Molina, M. A. Baños, J. Giménez, and S. Esplugas, "Degradation of chlorophenols by means of advanced oxidation processes: a general review," Applied Catalysis B: Environmental, vol. 47, no. 4, pp. 219-256, 2004.

[41] M. M. Ba-Abbad, A. A. Al-Amiery, A. Mohamad, and M. Takriff, "Toxicity evaluation for low concentration of chlorophenols under solar radiation using zinc oxide $(\mathrm{ZnO})$ nanoparticles," International Journal of Physical Sciences, vol. 7, no. 1, pp. 48-52, 2012.

[42] M. M. Ba-Abbad, A. A. H. Kadhum, A. Bakar Mohamad, M. S. Takriff, and K. Sopian, "The effect of process parameters on the size of $\mathrm{ZnO}$ nanoparticles synthesized via the sol-gel technique," Journal of Alloys and Compounds, vol. 550, pp. 63-70, 2013.

[43] S. Cao, K. L. Yeung, J. K. C. Kwan, P. M. T. To, and S. C. T. Yu, "An investigation of the performance of catalytic aerogel filters," Applied Catalysis B: Environmental, vol. 86, no. 3-4, pp. 127-136, 2009.

[44] N. Yao, S. Cao, and K. L. Yeung, "Mesoporous $\mathrm{TiO}_{2}-\mathrm{SiO}_{2}$ aerogels with hierarchal pore structures," Microporous and Mesoporous Materials, vol. 117, no. 3, pp. 570-579, 2009.

[45] J. S. Lee, K. H. You, and C. B. Park, "Highly photoactive, low bandgap $\mathrm{TiO}_{2}$ nanoparticles wrapped by graphene," Advanced Materials, vol. 24, no. 8, pp. 1084-1088, 2012.

[46] A. Sionkowska, "The influence of methylene blue on the photochemical stability of collagen," Polymer Degradation and Stability, vol. 67, no. 1, pp. 79-83, 2000.

[47] A. Adán-Más and D. Wei, "Photoelectrochemical properties of graphene and its derivatives," Nanomaterials, vol. 3, no. 3, pp. 325-356, 2013.

[48] H. N. Tien, V. H. Luan, L. T. Hoa et al., "One-pot synthesis of a reduced graphene oxide-zinc oxide sphere composite and its use as a visible light photocatalyst," Chemical Engineering Journal, vol. 229, pp. 126-133, 2013. 

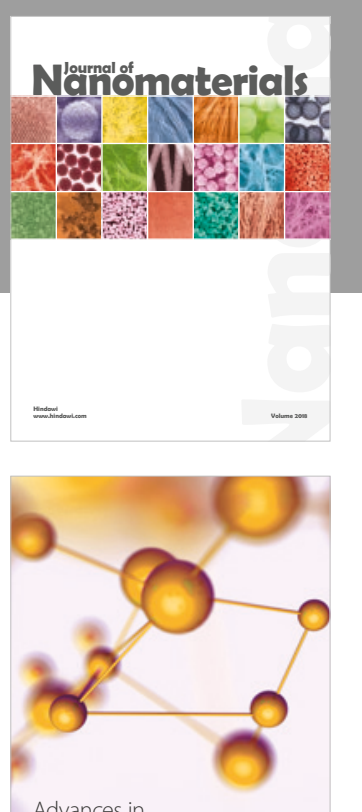

Physical Chemistry


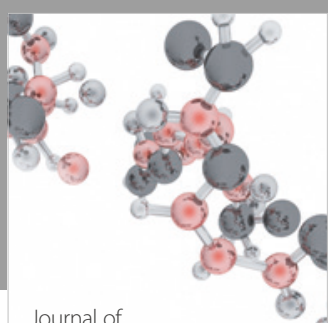

Analytical Methods

in Chemistry

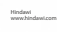



The Scientific World Journal

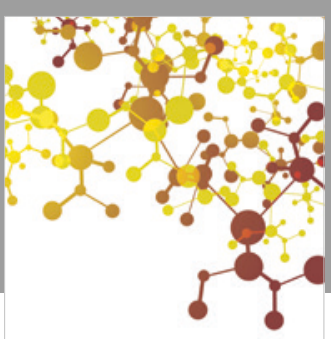

Journal of

Applied Chemistry
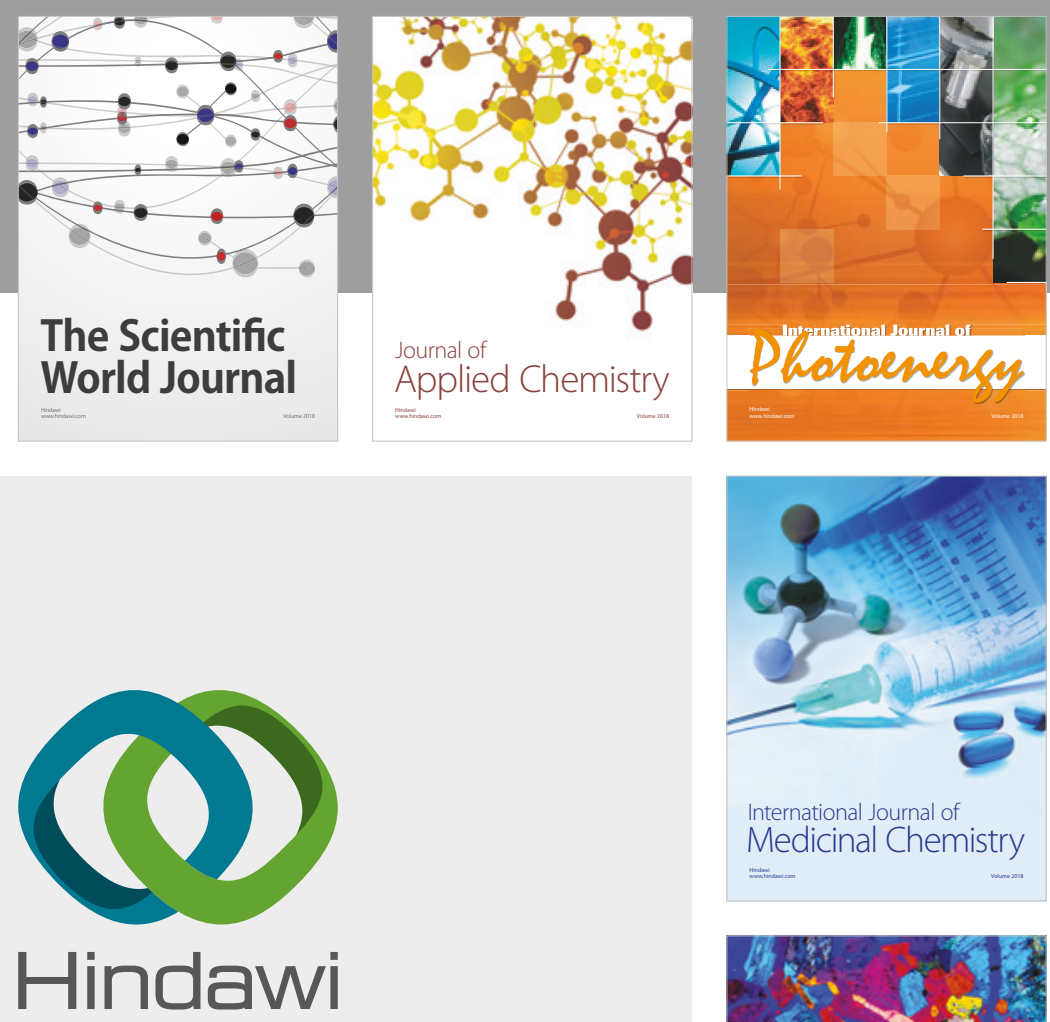

Submit your manuscripts at

www.hindawi.com
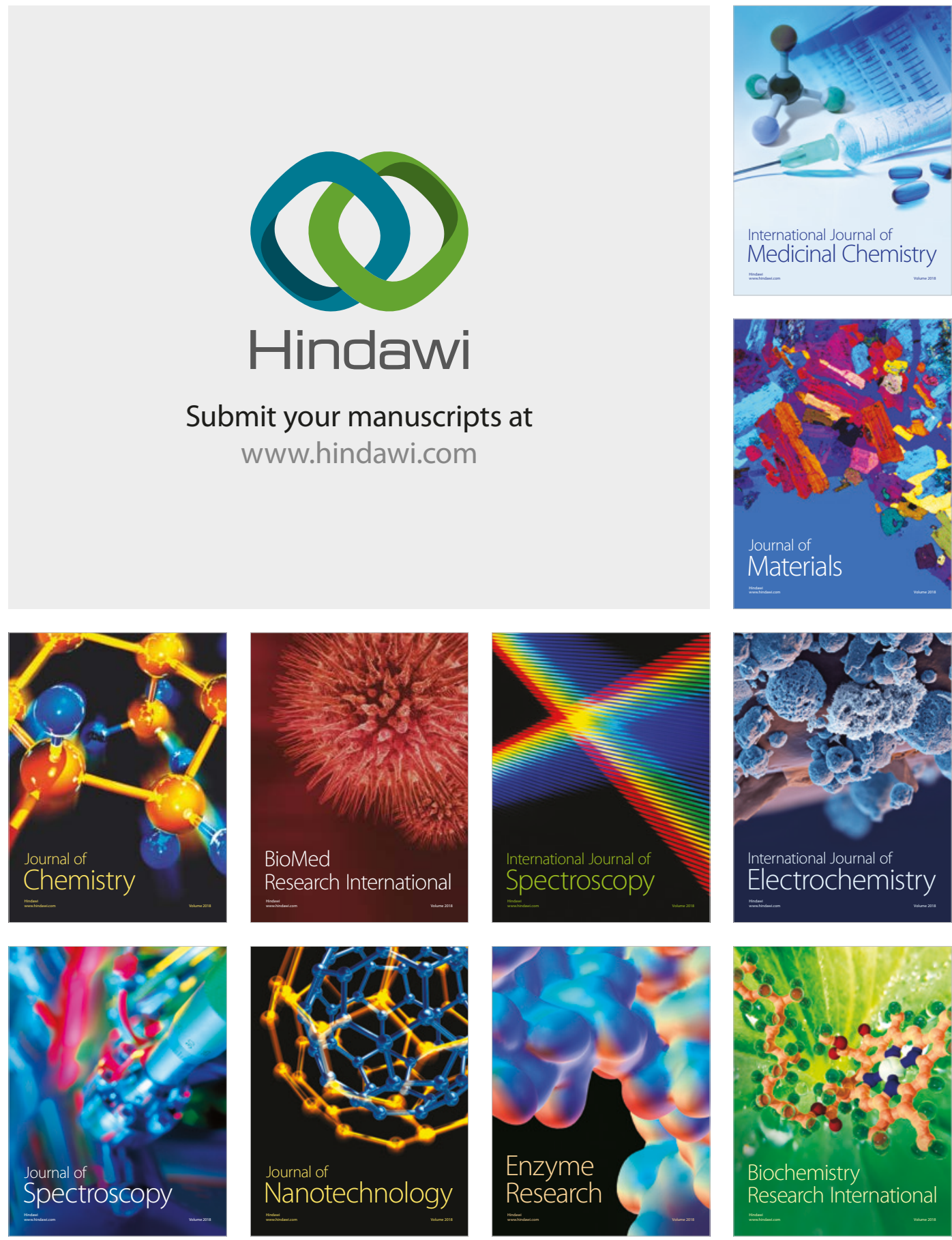
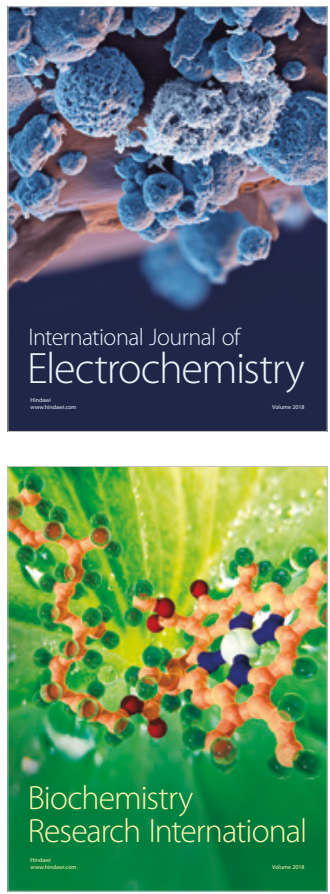